\title{
The Dominicans' Photographic Collection in Jerusalem: Beyond a Catholic Perception of the Holy Land?
}

\author{
Norig Neveu and Karène Sanchez Summerer
}

The Arabs, and chiefly the young among them who are cultivated, are becoming aware of their right to be considered indigenous. We need to remember that. Zionism could be the catalyst to bring about the fusion of Arab society in Palestine.

15 June 1918, ANTONIN JAUSSEN ${ }^{1}$

At the end of the First World War, having lived in Palestine for more than thirty years, at the École Biblique et archéologique française de Jérusalem (EBAF), the Dominican Antonin Jaussen was an expert observer of the local situation as well as the international engagement in Palestine, challenging what he considered to be the international lack of respect for local populations and elites in the region. ${ }^{2}$ Many Dominicans from his generation made an important contribution to visual production during the British Mandate in Palestine, given the strong relationship to their mission field and their training in historical and archaeological methodology, along with the increasing availability of light, transportable cameras.

1 Dispatch from Antonin Jaussen du 15 juin 1918, in Jean-Jacques Pérennès, Le Père Antonin Jaussen, o.p., (1871-1962). Une passion pour l'Orient musulman (Paris: Le Cerf, 2012), 76. We are grateful to Emeritus Professor at the École biblique et archéologique française de Jérusalem, Jean Michel de Tarragon and to the Professor of Archaeology Jean Baptiste Humbert for opening the photographic collection, their multiple answers, the several and 'chaleureux' coffee breaks with many discussions in December 2018 and April 2019, as well as the many visits in recent years and for his precious advice on our article. We remain the only persons responsible for the content.

2 H. Laurens, "Jaussen en Arabie," in Photographies d'Arabie, Hedjaz 1907-1917, ed. Brahim Alaoui (Paris: IMA, 1999), 32. 
The EBAF was founded in 1890 within the Dominican priory of St Stephen ${ }^{3}$ by Marie-Joseph Lagrange O.P. $\left(1855^{-1938)}\right.$ as a research institution. ${ }^{4}$ The school was first called the École pratique d'etudes bibliques, inspired by the recently-created institution in Paris (1868). ${ }^{5}$ For Lagrange, members of the school were to collect and produce information regarding Palestine and the Holy Land. The methodological specificity he encouraged was the study of the Bible in its physical and cultural context. The Dominicans of the 'first generation'6 (1890-1940) on whom this article will focus were specialised in different subjects, from epigraphy to Assyriology and geography to ethnology. From 1920, the institution became the École biblique et archéologique de Jérusalem (French Archaeological and Biblical School of Jerusalem) with the support of the French Académie des Inscriptions et Belles-Lettres (Paris). ${ }^{7}$ In 1892, the Biblical school launched its journal, La Revue Biblique, where scholarly results were published, including photographs. ${ }^{8}$

From the early twentieth century, photographs became embedded as evidence for the Dominicans of the Biblical school the development of their scholarly methodology. This echoes the attempt to develop a scientific method promoted by Salzmann from the 185 os for documenting archaeological sites. ${ }^{9}$ However, the photograph taken by the EBAF Friars reveal to a semantic turn in the use of photography, no longer as a tool for representing projection over a territory but as scientific evidence about it. Unlike commercial photographers

3 St Stephen's was established in 1882 in Jerusalem as a Dominican priory.

4 Marie-Joseph Lagrange, a Dominican exegete, was a central figure in the development of Biblical studies in the nineteenth century. He is especially well known for being one of the precursors of the historical method in Catholic exegesis. See Bernard Montagnes, Marie-Joseph Lagrange, Une biographie critique (Paris: Le Cerf, 2005).

5 T.N. Clark, Prophets and Patrons: the French University and the Emergence of the Social Sciences (Cambridge: Harvard University Press, 1973), 42-45; Jacques Revel, ed., Une école pour les sciences sociales. De la VI e section de l'EPHE, à l'École pratique des hautes études en sciences sociales (Paris: Le Cerf, 1996), 11-12.

6 Marie-Antonin Jaussen (1871-1962), Antoine-Raphäl Savignac (1874-1951), Louis-Hugues Vincent (1872-1960), Felix-Marie Abel (1878-1953), Édouard-Paul Dhorme (1881-1966). On the history of the EBAF, D. Trimbur, Une école française à Jérusalem. De l'École Pratique d'Etudes bibliques des Dominicains à l'École Biblique et Archéologique Française de Jérusalem (Paris: Le Cerf, 2002). The author does not mention the photographic collection.

7 French learned society devoted to Humanities, created in 1663, one of the five academies of the Institut de France.

8 Up to 1923, the editor of the journal was Marie-Joseph Lagrange, followed by Édouard-Paul Dhorme (until 1931), then by Louis-Hugues Vincent (until 1938) and Roland de Vaux (until 1953) and others after the Mandate period.

9 Sary Zananiri; "From Still to Moving Image: Shifting Representation of Jerusalem and Palestinians in the Western Biblical Imaginary", Jerusalem Quarterly 67 (2016): 64-81. 
so prevalent in the region, photography was used to document the findings of the archaeological expeditions much like the rubbings, drawings and sketches had previously. In this vein, they were projected during lectures or published in the Revue Biblique. The continuous interest of the Dominican Friars in photography throughout the twentieth and twenty-first centuries resulted in the current photographic collection of the EBAF. Besides pictures taken by the Dominicans, the current collection also includes digitised photographs from the other Catholic institutions in Palestine. ${ }^{10}$ With more than 30,000 glass plates, photographs and black and white and coloured slides, the collection of the EBAF is one of the most extensive photographic collections of the so-called 'Holy Land' (Palestine and the Middle East more broadly) preserved today.

Research on Palestine has been influential in the way visual iconography has been regarded as a valuable source for historians. ${ }^{11}$ The EBAF photographs presented in the recent historiography on Ottoman and British Mandate Palestine dealt mainly with archaeological sites, landscapes and monuments, with only a few focused on people. ${ }^{12}$ The main publications concern the his-

10 Latin Patriarchate of Jerusalem, Assumptionists, White Fathers, Salesians, Jesuits of the Pontifical Biblical Institute, Lazarists, Betharram Fathers, Rosary Sisters, Sisters of Zion, St Joseph Sisters, the German Paulus Haus and the Albright Institute of Archaeology.

11 Eyal Onne, The Photographic Heritage of the Holy Land, 1839-1914 (Manchester: Manchester Polytechnic, 1980), Sarah Graham-Brown, Palestinians and their Society, 1880-1946. A photographic Essay (London: Quarter Books, 1980); Mounira Khemir, L'orientalisme. L'Orient des photographes au XIX $X^{e}$ siècle (Paris: Photo-Poche, 1994); Nissan Perez, Visions d'Orient (Jerusalem: Israel Museum, 1995); Pierre Fournié and Jean-Louis Riccioli, La France et le Proche-Orient, 1916-1946, Une chronique photographique de la présence française en Syrie et au Liban, en Palestine au Hedjaz et en Cilicie (Paris: Casterman, 1996); Issam Nassar, "Familial Snapshots: Representing Palestine in the Work of the First Local Photographers," History \& Memory 18, no. 2 (2006); 139-155; Zeynep Çelik, "Photographing Mundane Modernity," in Camera Ottomana: Photography and Modernity in the Ottoman Empire, 1840-1914, eds. Zeynep Çelik and Edhem Eldem (Istanbul: Koç University Press, 2015), 154-200.

12 The EBAF published catalogues deal mainly with the Ottoman period. Itinéraires bibliques (1995), catalogue of the exhibition at the Institut du monde arabe, Paris 17/01-30/04/1995. The only EBAF catalogue dealing with the post-Ottoman period is Chrétiens d'Orient, Institut du monde arabe \& Centre régional de la photographie Nord Pas-de-Calais (6o photographs from EBAF), first catalogue to present photographs that were non-archaeological and dealing with all indigenous populations. Walid Khalidi, Before Their Diaspora, A Photographic History of the Palestinians 1876-1948 (Washington D.C.: Institute for Palestine Studies, 1991); Elias Sanbar, ed., Jérusalem et la Palestine, Photographies de l'École Biblique de Jérusalem (Paris: Hazan, 2013); Elias Sanbar, Les Palestiniens. La photographie d'une terre et de son peuple de 1839 à nos jours (Paris: Hazan, 2004). 
tory of Jordan, Oriental Christianity, the Holy Land or Palestine. ${ }^{13}$ Beyond a Biblical studies focused approach that favoured archaeological photographs, the Dominicans and the Catholic missionaries showed an interest across different segments of society, through the lens of Europeans in daily contact with the Arab populations of the region. How did photographs present scholarly actions of collecting local knowledge, theatre and music, education and medicine developing in these Catholic institutions? Is an Arabisation of the clergy noticeable from the photographers' points of view?

During two research projects on Christian communities at the end of the Ottoman Palestine and the British Mandate, ${ }^{14}$ we came across an exhibition organised by J.-M. de Tarragon and J.-B. Humbert 'Visages d'Orient' tackling the question of the indigenous population. Reflecting with them on the reasons for such an exhibition and the relations of Jaussen to his Arab fellows, the questions that progressively came to our mind were the ways to 'think about and to think with images ${ }^{15}$ within our historical approach. How can we capture, through visual representations, the historical changes in Palestine but also within the scientific perspective of EBAF and other Catholic institutions in Palestine? To what extent did the First World War and the Balfour Declaration change the Dominican perception of Palestinian society and communities? How can we view the photographic collections through the lens of ethnography from the current day, given the different approaches to the production of photography at the time they were produced? From this perspective, how did the Dominican's view - with the example of Jaussen - differ from that of other Catholic organisations? These collections will be decoded as 'action-sources', bearers of a discourse on the history of Palestine at the beginning of the twentieth century. We shall first analyse the history of the photographers and the collection itself, then discuss the Dominican ethnographic approach via the anthropological and photographic study of Nablus. Finally, we will envisage the evolution of the broader corpus of Catholic missionary photographs and the missionaries' perception of Palestinian Arab society.

13 Géraldine Chatelard and Jean-Michel de Tarragon, L'Empire et le royaume. La Jordanie vue par l'École biblique et archéologique française de Jérusalem (1893-1935) (Amman: Centre culturel français d'Amman, 2006); Sanbar, Jérusalem et la Palestine; Sanbar, Les Palestiniens.

14 The Nwo project Van Morsel (the Dutch Research Council), thanks to which we could help in acquiring specific material for photographic preservation and classification, helping data management, and the international research consortium MisSMO, https:// missmo.hypotheses.org/research-program.

15 Gregory Stanczak, Visual research methods: Image, Society and Representations (Thousand Oaks, CA: SAGE Publications, 2007), 1-22, 83-120. 


\section{The Constitution of the EBAF Photographic Collection}

The constitution of today's collection draws together a multiplicity of views of Palestine and the broader region. As well as the collections produced by the Dominican Friars of the Biblical School, it includes collections by a number of different Catholic institutions present in the region, including the Assumptionist Fathers of Notre-Dame de France, Betharram Fathers, Médebielle collection, White Fathers of Saint Anne of Jerusalem, the Salesians, Catholic order of the Rosary Sisters, the Sisters of Sion as well as some images produced by commercial photographers like Khalil Ra'ad and the American Colony Photographic Department.

The photographic collection of the Biblical school is mainly composed of glass plates. This illustrates, according to Jean-Michel de Tarragon, Professor Emeritus and archivist of the photographs at the EBAF:

A particularity of the Dominican collection: at this time, it was not considered as a collection, offered to an audience. It was a scientific tool for internal use. Between colleagues, with a simple conversation, one was able to find this or that series of negative glasses [...]. Originally, the building did not house a photographic library as such: the plates remained in the cells of the Friars according to the subjects they had treated. After their death, a centralised archiving process was decided. ${ }^{16}$

The fact that the Dominicans kept their photographs in their cells explains why they rarely signed their photographs and did not date them. This is one of the difficulties faced by the archivist and the historian while using this collection. Some answers can be found in the Revue Biblique or the volumes published by the Dominicans.

In many ways, the broader context of the collection points to some of the complexities of how to address them. On the one hand, the collection is vested in the context of missionaries in and their activities in Palestine. On the other, they are also a form of scientific engagement as part of historical and archaeological methodologies. Overlapping this division is of course the question of ethnography. Whether images where taken as part of the documentation of

16 Interview with Jean-Michel de Tarragon, April 2019, Karène Sanchez Summerer and Norig Neveu. 'Those include 2,448 stereoscopic glass negatives. Then, we could add 1,003 stereoscopic glass positives, for projection or $3 \mathrm{D}$ viewing through a viewing machine, not scanned because 95 percent are duplicates of negatives included among the bulk of the twelve thousand scans.' 
missionary activities or scientific endeavour, where populations are concerned, the collections of EBAF that image people constitute a useful record of interactions.

The tensions at play between documenting missionary activities and scholarly documentation also point to the multiple frameworks that enable an understanding of European Catholic networks and indigenous communities across multiple genres of photography. Given the complete and comprehensive nature of the photographic archive, we also have a rare opportunity to address this relationship with knowledge that all available material is present. Further, we can regard missionaries' adoption of photography and the transformations of modernity not just as affecting the indigenous communities with which the missionaries worked, but indeed transforming the missionaries themselves and the nature of their work. In many regards, the multiple photographic lenses of these Catholic collections give us as much information about the photographers as they do about the photographic subjects.

The digitisation process started in 2001 with the glass plates; many Catholic communities accepted the offer to scan their collections free of charge, receiving back their originals and a CD set. In exchange, the EBAF obtained an official written agreement for the Right of Use to the scans. ${ }^{17} \mathrm{~J}$.-M. de Tarragon chose to include the imperfections, damage, captions, and in some cases handwritten notes on the surfaces of the prints - editorial comments, for example, or simply informal notes jotted down by previous owners or viewers. The vast majority of the Dominican collection and the Catholic missionaries' collections have been scanned. Many pictures, glued into albums, were first dismounted before they were scanned and duplicated. The structuring of the photographic collection does not correspond to the ordering of the photographers. The notion of 'author/photographer' seems of no importance here. Photographs are inventoried and organised according to a geographical classification (by mission fields) and thematic (according to categories such as 'Churches', 'School', 'Medico-social', 'Youth', etc.).

Four thousand positive square glass plates (non-stereoscopic) are in the collection, some of them genuine American Colony photographs from before the time of Eric Matson, and independent from the collection available in the Library of Congress in Washington, DC. The twelve thousand negatives

17 J.-M. de Tarragon also scanned two albums stolen in 1948 from the Ra'ad Studio, on loan from Elli Schiller, the Israeli historian who was interested in the photographic collection of the EBAF (the albums subsequently perished in an accidental home fire later). The photographs were small paper prints, not such high quality (many were scratched), but many of them included English captions. The collection also includes 285 pictures taken by Bonfils. 
are private, being the work of the Dominicans during a period spanning from 1890 to around 1952. Since the 199os, the EBAF photographic collection has been expanded. In 1994, the Assumptionist Fathers of Notre Dame de France transferred to the EBAF 1,603 glass plates of different sizes, taken between 1888 and 1930 in Palestine and neighbouring countries. A few years later, the contemporary Assumptionists of St Pierre-en-Gallicante authorised Jean-Michel de Tarragon to digitise the 302 paper prints from the large Notre Dame de France photograph albums (the original glass plates are missing). Several Catholic missionary institutions progressively asked J.-M. de Tarragon to digitise their photographs (Fig. 4.1).$^{18}$ We consider, in this article, all the Catholic institutions' photographs present in the EBAF collection.

The Catholic missionaries' photographs range from uncatalogued boxes or albums at one end of the scale to carefully preserved, well-organised and semi-professionally documented collections numbering hundreds of thousands of photographs at the other. That makes the EBAF photographic collection a valuable testimony of the social, political and religious history of Palestine. Many photographs concern the period of the British Mandate, although J.-M. de Tarragon has initially chosen to focus on photographs from the Ottoman period.

Unlike other photographic archives in the region, ${ }^{19}$ the Dominican photographs were never destroyed or looted, in spite of their proximity to the conflict zone in 1948. It is in this context, aware that the Dominicans had never sold their pictures, that J.-M. de Tarragon started the digitisation. However, the action was not always understood by his peers as the EBAF as an academic

18 They include the Schmidt school photographs, the former German Paulus Hospiz (139 unpublished photographs, dated between 1907 and 1911). In 2008, the glass plates of the White Fathers of St Anne were digitised (701 glass plates). Most of them are unpublished, and the oldest date from before the foundation of the EBAF (from about 1875 to 1939). In this collection, in addition to the glass plates, there are about 872 old photographs on paper (digitised), dealing mainly with the Melkite community. Later, an important addition was made to the collection with the digitisation of the pictures of the Latin Patriarchate and the seminary of Beit Jala and the photographs taken by the Latin Patriarchate's former historian, Pierre Médebielle (so far 2,553 photographs). The collection also includes 366 prints from the album of the Italian Salesian fathers of Beit Jimal (from 1930 to 1940) and the 1,740 photographs, negatives and glass plates and acetate photographs from the Jesuits. This collection or donation process is currently continuing; some feminine orders have recently accepted to share their entire photographic collection (Sisters of Zion, Rosary Sisters).

19 About destruction and dispersion of photographic fund, see in this volume Rona Sela about Khalī Ra'ad's collection and Rachel Lev about the American Colony collection. 


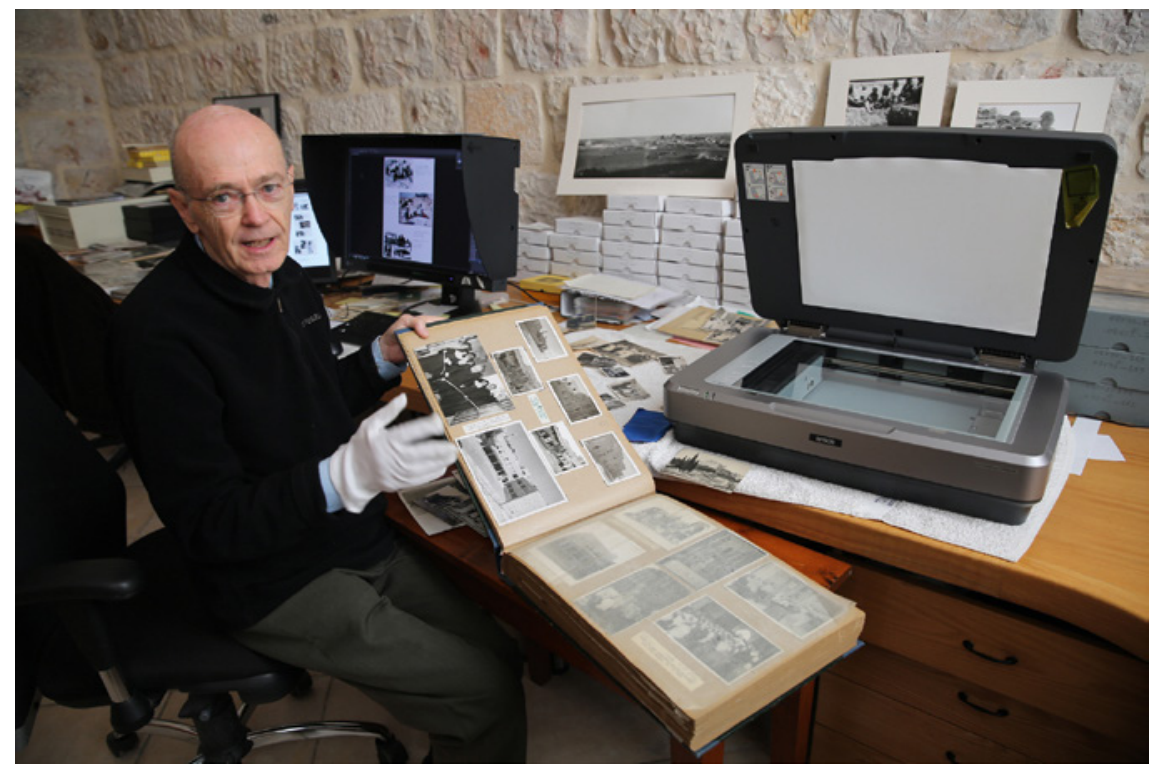

FIGURE 4.1 Preservation, scanning and cataloguing of the EBAF photographs by J.M. de Tarragon, April 2015. Latin Patriarchate archives digitisation

institution has focused on textual archives. ${ }^{20}$ It thus had no image 'policy', nor image 'spaces' in the sense of a place devoted to preservation and consultation. Linked to some French and later Palestinian historians, J.-M. de Tarragon promoted his initiative among his peers and wider audiences in France. He initiated several exhibitions, collaborated occasionally with researchers and obtained financial support to start the digitisation.

As far as the posterity of the EBAF photothèque is concerned, J.-M. de Tarragon has addressed the next challenge: namely, the need to consolidate searches across several physically and administratively separate collections. He is thinking of a potential platform, a 'confederation' of archival source materials, that would, at a later stage, possibly collate what is learned in one mission collection with what can be found in another. Photographs are inevitably linked to many text-based historical records which contain information that can often be linked to the individuals, events, and subjects depicted in the missionary photographs (eg. the diaries/daily life reports of the Dominican priory and

20 The EBAF photographs are not part of the recent initiative by the BNF (National French Library) Bibliothèques d'Orient, like many other missionary congregations, though A. Jaussen is mentioned as an important actor, "Antonin Jaussen (1871-1962)," Bibliothèques d'Orient. 
activities). They can function as meta-data and allow a finer view of the photographers and the context of their approaches. The potential users would be able to define the search by time, place and theme, sorting the results according to the categories, descriptors and keywords used when photographs were scanned and added to the record. Later on, the viewers familiar with the time, place and people involved would be able to contribute information that the EBAF could consider for incorporation into the electronic record. Another step, linked to the memorial challenges, data availability, the need of preservation and the property/copyrights issues of private institutions.

\subsection{The History of the Photographers: Looking for Biblical Lands}

The first pictures of the Bible School were taken by M.-J. Lagrange during a trip from Egypt to Jerusalem, during the Spring of 189o. Dominicans of the first generation were encouraged by Lagrange to use photography during their investigations. From 1900, with a peak between 1905 and 1907, Antonin Jaussen, Raphaël Savignac, Louis-Hugues Vincent, and Felix-Marie Abel started to take up photography. ${ }^{21}$ It was used as scientific evidence which determined its composition. This appears clearly in comparing the pictures taken by the Dominicans and the Assumptionists in the early twentieth century. The latter would focus on the representation of a romanticised Holy Land as Bonfils had done earlier. ${ }^{22}$ This asymmetrical use of photography between the different orders had technical reasons: the Dominicans rarely printed their photographs as they were not produced to be sold to pilgrims. As they aimed to document the Bible in its context, the pictures taken by the Dominicans proposed an alternative representation to the Biblical iconography so common to the photographic milieus in Jerusalem. ${ }^{23}$

Dominicans usually worked in pairs, for instance Jaussen and Savignac or Abel and Vincent. Jaussen and Savignac held a special place because of both the quality and the quantity of their photographic productions. ${ }^{24}$ Most of the

21 Jean-Michel de Tarragon, "The photographic-library of the Dominican of Jerusalem," in Jérusalem et la Palestine, Photographies de l'Ecole Biblique de Jérusalem, ed. Elias Sanbar (Paris: Hazan, 2013), 163-175; "Antonin Jaussen (1871-1962)," Patrimoines partagés, Bibliothèques d'Orient, accessed 12/o1/2020, https://heritage.bnf.fr/bibliothequesorient/ fr/antonin-jaussen-article.

22 Estelle Villeneuve, Jacques Nieuvarts, Alain Marchadour and Benoît Grière, Terre sainte. Les premières photographies (Paris: Bayard, 2010); Gavin Carney, "Bonfils and the Early Photography of the Near East," Harvard Library Bulletin 26, no. 4 (1978): 442-470.

23 Issam Nassar, "Biblification' in the Service of Colonialism. Jerusalem in Nineteenthcentury Photography," Third Text 20 (3): 317-326.

24 The other Dominicans who took photographs were Paul-Marie Séjourné, Raphaël Tonneau, Bertrand Carrière, Pierre Benoit and Roland de Vaux. 
photographs in the collection are theirs, especially the glass plates. Jaussen specialised in stereoscopic views while Savignac mostly produced classical glass-negative photographs. ${ }^{25}$

Jaussen's first photographs were probably taken in Damascus in 1897 during the School's study trip. The history of the photographic collection is intimately linked to that of the EBAF, whose programme of studies included annual trips, the 'Biblical Caravan', to discover the lands of the Bible (Fig. 4.2). They started in and around Jerusalem and gradually concerned visits to the 'Holy Land' and the region (as far as Transjordan, Egypt, Hauran, Biläd al-Shām). The purpose of the caravan, made by camel or horseback, was to observe ancient archaeological sites as well as the natural environment and populations of the region. ${ }^{26}$ This approach was associated with many other techniques for scientific recording, including note-taking, drawing, rubbings and, very soon, photography. The function of photography, in the context of a positivist approach, was considered as valuable as rubbings was to provide evidence to illustrate or justify discoveries or observations. The photographs of the EBAF collection were taken by scientific amateurs who did not cultivate an artistic practice, even if the latter is appreciable in some photographs.

The Dominicans of EBAF also made expeditions for other scientific purposes, as for example Jaussen's exhibition to Petra in 1896 or to the Negev in 1904 sponsored by the Académie des Inscriptions et Belles-lettres. Some expeditions are well documented in the photographic collection, such as the one to Hijāz $(1907,1909,1910)$ or to the Dead Sea (1908-1909). Until the First World War, most of the pictures focused on archaeological sites, landscapes and general views of cities. Individuals usually appeared in support of scientific knowledge, notably as scale markers indicating the size of an archaeological site. ${ }^{27}$ Apart from Jaussen's famous portraits of some members of the Azayzāt tribe of Mādabā, few photographs are portraits of local people. Most of the time during their expeditions, the Dominicans would be hosted by Latin Catholic missionaries. The pictures document the expansion of these missions, their schools and hospitals. The photographic collection constitutes precious

25 Jean-Michel de Tarragon, "Holy Land Pilgrimage through Historical Photography," Jerusalem Quarterly 78 (2019): 93-111, available via https://www.palestine-studies.org/ sites/default/files/jq-articles/Pages_from_JQ_78_-_Tarragon_1.pdf.

26 Conferences attended by a big audience, Diaries of St Stephen's priory, Biblical and Archaeological School of Jerusalem, for example: 19/o2/1919: Savignac on Nabatean art; 5/o51920, Savignac on Palmyre.

27 E. Barromi, "Archeology, Zionism and Photography in Palestine: Analysis of the Use of Dimensions of People in Photographs", Journal of Landscape Ecology 10, no. 3 (2017): 49-57. 


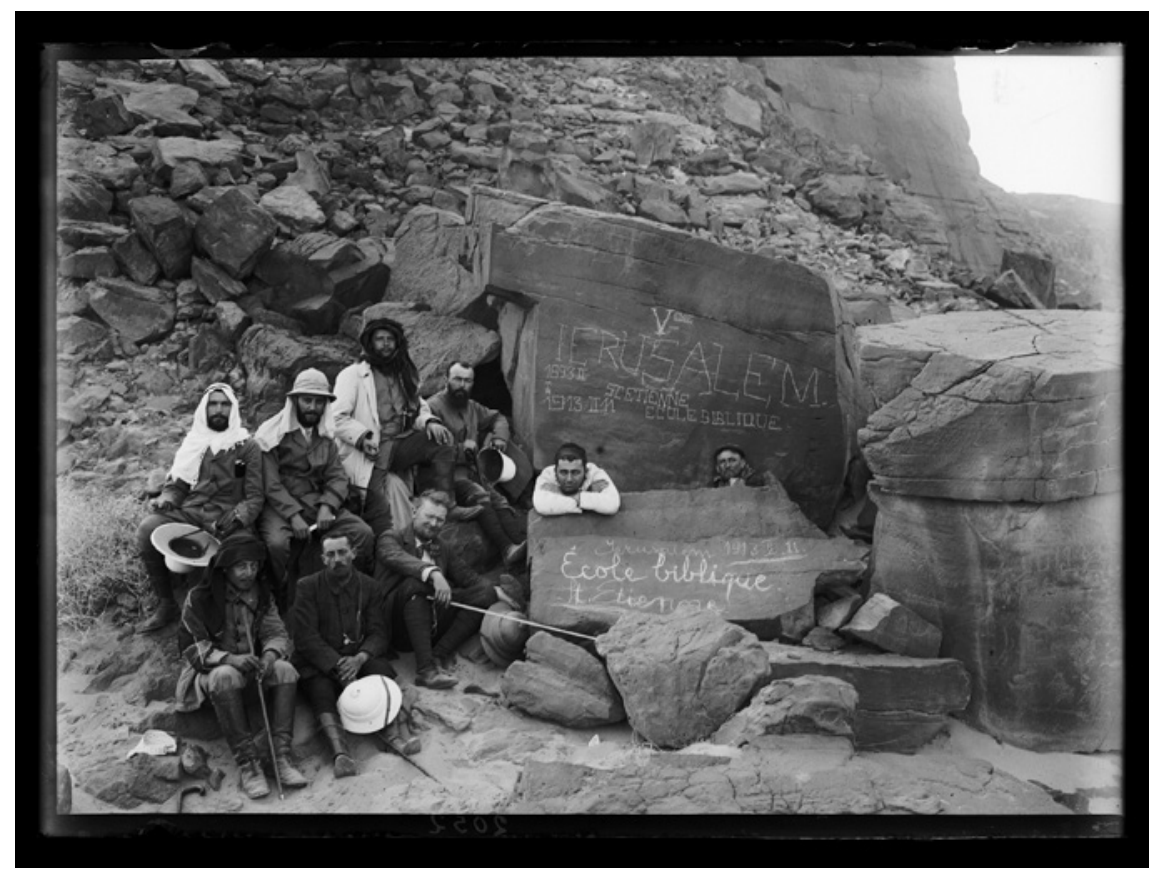

FIGURE 4.2 Biblical caravan, 1913. Photographer unknown IMAGE COURTESY OF EBAF

sources about the history of missionary institutions from the late nineteenth century especially the EBAF (the Friars, the students, the library, the expansion of the priory), but also St Anne's Melkite seminary ${ }^{28}$ or the Sisters of Sion's educational activities.

The photographic collection also provides important evidence for the period of the First World War as some Dominicans including Jaussen and Savignac served as intelligence officers for the French Navy. Based in Port Sa'ìd, they met their British counterpart, T.E. Lawrence. The collection also includes the famous picture of Allenby entering Jerusalem in 1917. After the end of the War, the activity of St Stephen's priory started anew in 1920. EBAF members focused on archaeology and Palestinian cities. During the first years of the Mandate, Dominicans could access the two major Palestinian holy sites: the Dome of the Rock (Harām al-Sharîf) in Jerusalem and the Cave of the Patriarchs (Harām al-Ibrahīmī) in Hebron. They focused less on pilgrimages and processions and more on the interiors of the sites, their architecture and ornaments.

28 The Melkite Church follows the dogmas of the Roman Church and the Byzantine or Eastern rite. 
The Dominicans were self-taught photographers. For their training, they received the help of the Assumptionists of Notre-Dame de France (NDF). By the end of the nineteenth century, the Assumptionists had established a press service in Jerusalem. In the 189 os, they 'contributed to immortalising Palestine and Jerusalem as pilgrimage sites through a photography service.'29 From the end of the nineteenth century the Dominicans and the Assumptionists developed scientific collaborations regarding archaeology, especially during the excavations of St Peter in Gallicantu. ${ }^{30}$ These collaborations extended to technical training in photography.

The techniques and training of the Dominicans had an impact on the way they took photographs. Conversely, their approach also conditioned each Friar's choice of photographic equipment. ${ }^{31}$ As lighter, more robust and more portable cameras were developed, and factory-made negatives became available, some photographs give the impression of the photographers' being closer to the subjects photographed. While Savignac had a more static and frontal approach due to the tripod chambers, the installation of the camera in the field and the treatment of glass plates, Jaussen made reports with more easily manoeuvrable equipment, which allowed him to obtain stereoscopes, which were more vivid, and to photograph people in situ. The very composition of the photographs also depended on the scientific goals of the Friars. Many of Jaussen's photographs reveal a desire to represent Middle Eastern social dynamics. He did not hesitate to take his camera into crowds to capture social events such as pilgrimages.

The plurality of visual narratives offered to the historian is one of the riches of the EBAF photographic collection. During the Dead Sea Expedition, for instance, Jaussen was photographing the encampments, the men on the ship's decks and so on, while Savignac was scientifically composing photography of landscapes. ${ }^{32}$ One can hardly argue that Jaussen restored 'the individual identity of the people portrayed, ${ }^{33}$ as the subalternity of the relationships between the Dominicans and the workers accompanying their expedition appears in many respects in the photographs.

29 Dominique Trimbur, "A French Presence in Palestine - Notre-Dame de France," Bulletin du Centre de recherche français à Jérusalem 3 (1998): 117-140.

30 Trimbur, "A French Presence in Palestine."

31 For a detailed list of the cameras used before the 195 os by the Dominicans see, De Tarragon, "The photographic library of the Dominicans of Jerusalem" and Renaud Escande, "Un jeu de regards: la photographie de Jaussen et Savignac à travers la croisière de l'École pratique d'Études bibliques autour de la mer Morte," in Antonin Jaussen. Sciences sociales occidentales et patrimoine arabe, eds. G. Chatelard and M. Tarawneh (Beirut: CERMOC, 1999), 109-110, available online https://books.openedition.org/ifpo/5326?lang=fr\#bodyftnı4. Escande, "Un jeu de regards," 110-111.

Nassar, "Familial Snapshots," 147. 
The originality of these photographs in comparison to other visual productions of the time - in particular that of Ra'ad or the American Colony - relates to its scholarly function as opposed to more popular commercial visual narratives. Thus, what can missionary, but also scholarly, photography teach us about social history? How can we trace the social history of Palestinian Arabs in these Catholic missionary archives? The diaries of St Stephen's priory covering the Mandate period reveal an intense activity of the Dominicans in terms of lecturing in the various scientific societies of Palestine especially the Catholic ones, ${ }^{34}$ but also in Europe. These thematic lectures were accompanied by the projection of photographs. Although these photographs were circulated in a number of scientific societies their influence on representations of Palestine within the scholarly community or a wider cultured public remains uncertain.

\section{2 \\ Picturing Palestine, Picturing the Holy Land: A Dominican Ethnography?}

Jaussen holds a special place in the Dominican scientific production of the time that must be considered in terms of the complementarity of skills. He is the precursor of a comprehensive approach to local societies and the production of ethnographic knowledge. His photographs are therefore both original compared to those of the other friars, while embodying the academic ambitions of his institution. Until the First World War, Jaussen's observations were mainly focused on Transjordan. ${ }^{35}$ Afterwards, he focused on urban dynamics and Palestine. ${ }^{36}$ If Jaussen's involvement as an intelligence agent during the First World War was considered as evidence of his link with the imperialist powers, ${ }^{37}$ his approach to collecting data and iconography was originally as an

34 For example: Catholic Club of Jaffa (Jaussen, 22 January 1927), students of St. Joseph (Abel, 11 April 1935, on the various monuments of the Haram eš-Šérif in Jerusalem) or the Palestine Oriental Society (8 April 1936). Diaries of St Stephen's priory, Biblical and Archaeological School of Jerusalem, Jerusalem.

35 Antonin Jaussen, Coutumes des Arabes au pays de Moab (Paris: Adrien-Maisonneuve, 1948).

36 See for instance Antonin Jaussen, "Trois inscription arabes inédites, du Haram d'Hébron," Revue Biblique (January 1923); Antonin Jaussen, "Inscriptions coufiques de la chaire du martyr al-Husayn, à Hébron," Revue Biblique (October 1923); Antonin Jaussen, "Inscription arabes de la ville d'Hébron," BIFAO (1924); Antonin Jaussen, "Inscriptions arabes de Naplouse," BIFAO (1924).

37 Roberto Mazza and Idir Ouahes, "For God and la Patrie: Antonin Jaussen Dominican and French Agent in the Middle East 1914-1920," First World War Studies 3, no. 2 (2012): $145^{-164 .}$ 
intermediary between ethnology, Biblical studies and Orientalist influences. How did the post-war period mark a change in his approach?

\subsection{Antonin Jaussen and Nablus, an Ethnographic Turning-point?}

Antonin Jaussen (1871-1962) settled in Jerusalem in 1890 where he was one of the first to become a professor at the EBAF. A specialist in Semitic languages, he began as an epigraphist. He carried out several periods of field research among the nomadic Arab tribes of the East of the River Jordan with an ethnographic interest. He pioneered work by studying the tribes and Bedouins of Transjordan, among whom he lived between 1901 and 1905. He published several articles in the Revue Biblique, Coutumes des Arabes au pays de Moab (Customs of the Arabs in the Land of Moab, Paris, 1908) and took several pictures of the life of the tribes of Transjordan.

In 1909, Max van Berchem ${ }^{38}$ described Jaussen's approach: 'Jaussen [investigator] prefers the discussion led by the investigator, in the middle of a group of interlocutors.' ${ }^{39}$ In this article, Max van Berchem refers to the works of Jaussen as ethnology. The question of Jaussen's inclusion among the first defenders of this discipline at the end of the nineteenth century is a matter of academic debate. ${ }^{40}$ This is due to the originality of his approach: the definition of a scientific protocol:

Wishing to know the nomads, I decided to go straight to the source and went to the desert to study the Bedouins. This work is therefore the result of my personal observations; it only contains data drawn directly from the Arabs. [...] I did not intend to defend a thesis or support a system; I wanted to see the facts and record observations [...] If I have reported certain laws or certain facts from the Bible, it is simply as a marker, not having as my aim to treat such an interesting subject. ${ }^{41}$

38 Max van Berchem (1863-1921) established Arabic epigraphy as a discipline. Trained in Leipzig, he had a doctorate. He also studied in the universities of Strasbourg and Berlin. He made his first voyage to the Orient in 1886, visiting Alexandria and Cairo. In 1888, he visited Palestine and Syria. From then on, he visited the Near East annually. See Sophie Makariou, "Van Berchem Max," in Dictionnaire des orientalistes de langue française, ed. François Pouillon (Paris: IISMM/Karthala, 2008), 948-949.

Max van Berchem, "Aux pays de Moab et d'Edom," Extract from Journal des Savants (Paris: Imprimerie nationale, 1909): 33-35.

40 Géraldine Chatelard and M. Tarawneh, eds., Antonin Jaussen. Sciences sociales occidentales et patrimoine arabe (Beirut: CERMOC, 1999).

41 Jaussen, Coutumes des Arabes au Pays de Moab, 2-3. 
Jaussen presents here a scientific method which was an innovation at the time. Jalabert states, that 'this Dominican's approach was part of a long tradition that considered the Arabic language, then Islamology and Bedouin ethnography as a means to a better understanding of the Bible.42 Jaussen's approach paradoxically claimed to be detached from Biblical exegesis, but only refers to its representatives rather than quoting the precursors of ethnographic studies such as Lane. ${ }^{43}$ Thus, until the First World War, Jaussen's work was at the crossroads of a nascent ethnography and reminiscences of Biblical and Orientalist scholarship productions. This was reflected in the themes he chose such as Bedouins, nomads and tribal social and religious dynamics. This ethnographic work represented an important turning-point within the academic activity of the EBAF. ${ }^{44}$

After serving as an intelligence agent for the French services, ${ }^{45}$ Jaussen returned to Jerusalem in 1918. He stayed there until 1927 when he was sent to Cairo by Lagrange to open a Dominican priory. In 1933, he founded the Dominican House of Oriental Studies in Cairo (IDEO). In Palestine under British Mandate, he no longer worked on Bedouins and tribes but started focusing on the social dynamics of Nablus and its surroundings which led to the publication of his book Coutumes palestiniennes. I. Naplouse et son district in 1927. He was familiar with the city where he had stayed during his travels and on which he had written an article in the Revue Biblique in 1905 about one of the sheikhs, Saad, an amulet producer. ${ }^{46}$ In the introduction of Coutumes palestiniennes, Jaussen mentions that:

Being unable to undertake a study of the whole of Palestine with its multiple contours and aspects, I have limited my observations to the region, and especially the town, of Nablus: a territory largely sheltered from foreign influence. [...] The method, already used in "Coutumes des Arabes", is the same here: an objective study of the facts; personal verification;

42 Cyrille Jalabert, "De l'exégèse biblique au monde arabe," in Antonin Jaussen. Sciences sociales occidentales et patrimoine arabe, eds. Géraldine Chatelard and Mohammed Tarawneh (Beirut: CERMOC, 1999), 69.

43 Ibid.

44 Jean-Michel de Tarragon, "Ethnographie," in L'Ancien testament. Cent ans d'exégèse à l'École biblique. Cahier de la Revue Biblique 28 (Paris: Gabalda, 1990), 19-44.

45 See Henry Laurens, "Jaussen et les services de renseignement français (1915-1919)," in Antonin Jaussen. Sciences sociales occidentales et patrimoine arabe, eds. Géraldine Chatelard and Mohammed Tarawneh (Beirut: CERMOC, 1999): 23-35.

46 Antonin Jaussen, "Le Cheikh Sa'ad ad-Din et les "djinn" à Naplouse," Revue Biblique (1905): $145^{-157}$. 
discussion with the indigenous people concerning some rather extraordinary assertions in order to get at the truth. ${ }^{47}$

The study on Nablus was conducted between 1923 and 1926. He observed the social dynamics in and around the city, conducted interviews with privileged interlocutors about the collective memory, habits and customs of the city dwellers. In an ethnological perspective, most of the cases mentioned by Jaussen are anonymised and only the first letters of the names are mentioned. In the study on Nablus, Jaussen confirms and refines his ethnographic approach and method. It is by its thematic, a study of a Palestinian city and its urban dynamics that his work on Nablus marks a turning-point.

\subsection{A French Pictorial and Ethnographic Study of an Historic 'Islamic City'?}

The result of Jaussen's research was published in 1927. The book is divided into 10 chapters focusing on the social dynamics of the city and its region. Several photographs were taken during the fieldwork with the help of Savignac, representing the urban landscape, the surroundings of the city, its workers and women (Fig. 4.3).Jaussen chose Nablus for a practical reason: his good relations with the French person in charge of the Catholic mission which opened in the 186os. ${ }^{48}$ In 1904, three French sisters from Saint-Joseph settled in Nablus and opened a dispensary. ${ }^{49}$ Jaussen used it as an observatory of urban life where he conducted observations and took photographs. He also chose Nablus because he pictured the city as protected from the upheavals that were transforming Palestine, including the British Mandate and Zionism:

A city lost in the mountains and off the beaten track, a city that is almost cut off from the movement of the world and which has no local resources: such a town does not feel the need for hard work. Under the pressure of modern times, it may tend to change; but today it has still kept its ancient

47 Antonin Jaussen, Coutumes palestiniennes. I. Naplouse et son district (Paris: Geuthner, 1927).

48 Jean Jacques Pérennès, Le Père Antonin Jaussen. At this period the mission was organised around a chapel, a school for boys and with the help of the Rosary Sisters, a school for girls; Karène Sanchez Summerer, "Réception et impacts de l'action éducative et sanitaire des sœurs de Saint Joseph (Naplouse) et des sœurs de Sion (Jérusalem) par les populations musulmanes rurales et urbaines (1870-1940)," in Histoire et Missions chrétiennes 22, eds. Nadine Beligand and Philippe Bourmaud (Paris: Karthala, 2012): 163-196.

49 Jean Métral, "Naplouse et son district: un essai de monographie urbaine," in Antonin Jaussen. Sciences sociales occidentales et patrimoine arabe, eds. Géraldine Chatelard and Mohammed Tarawneh (Beirut: CERMOC, 1999), 121-135. 


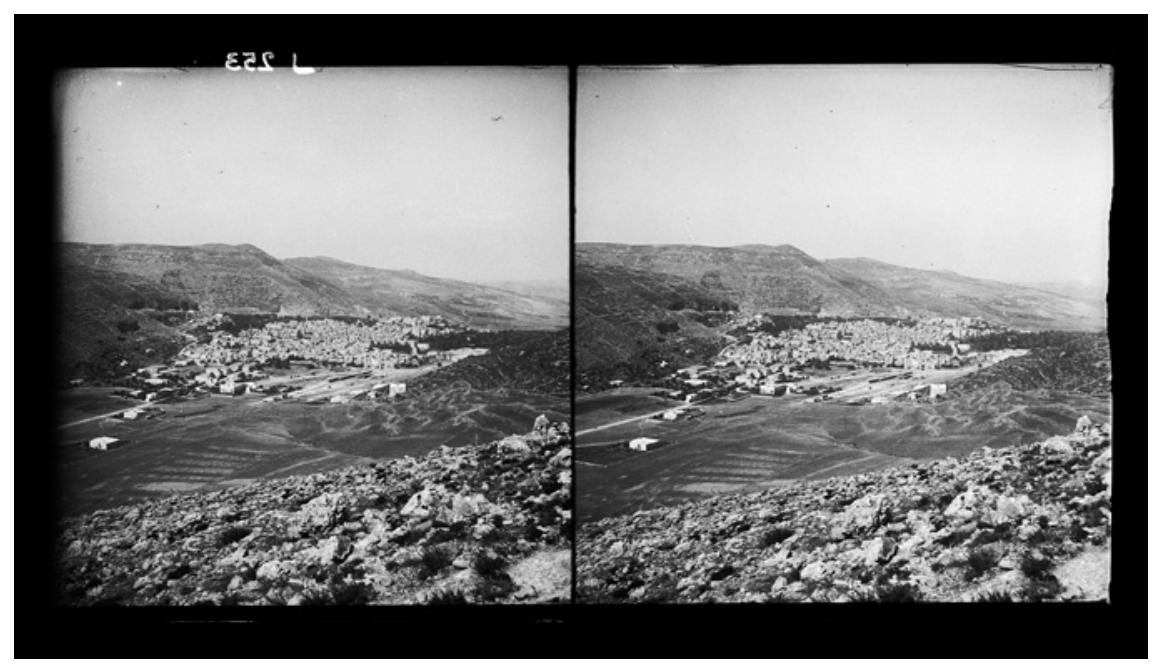

FIGURE 4.3 General view of Nablus, early 1920s. Antonin Jaussen. Digitised glass plate, OO248-Jo253

IMAGE COURTESY OF EBAF

organisation of work. [...] To a certain extent this organisation may evoke for us what industry was like in Samaria. ${ }^{50}$

Jaussen focuses on the traditional life of a Palestinian city rather than the profound transformations of the urban economy in the $1920 .^{51}$ The city seems detached from its historical evolution. If the book opens with a description of the topography of Nablus, it focuses mainly on its social structures, religion and mentality: women, family, important families and notables, work and religion. The importance given to the family as the basic social structure of urban social dynamics recalls his analysis of tribes in Ottoman Transjordan. For Jaussen, the urban identity of Nablus was inherited from its long-term history. This timeless dimension of urban dynamics echoes the Biblical perception of the Palestinian territory, but here with an emphasis of the Islamic heritage.

Since the early 18 th century, Jabal Nablus had been experiencing a process of social and economic integration between the city and the countryside. ${ }^{52}$ At the beginning of the Mandate period, Nablus remained the centre of a mutasarrifiyya (region) of 168 villages whose peasants depended on the important

50 Antonin Jaussen, Coutumes palestiniennes, 277.

51 Sarah Graham-Brown, "The Political Economy of Jabal Nablus, 1920-1948," in Studies and Social History of Palestine in the Nineteenth and Twentieth Centuries, ed. Roger Owen (London/Basingstoke: Macmillan, 1982) 88-176.

Bishara Doumani, Rediscovering Palestine: Merchants and Peasants in Jabal Nablus, 170o1900 (Berkeley: University of California Press, 1995). 


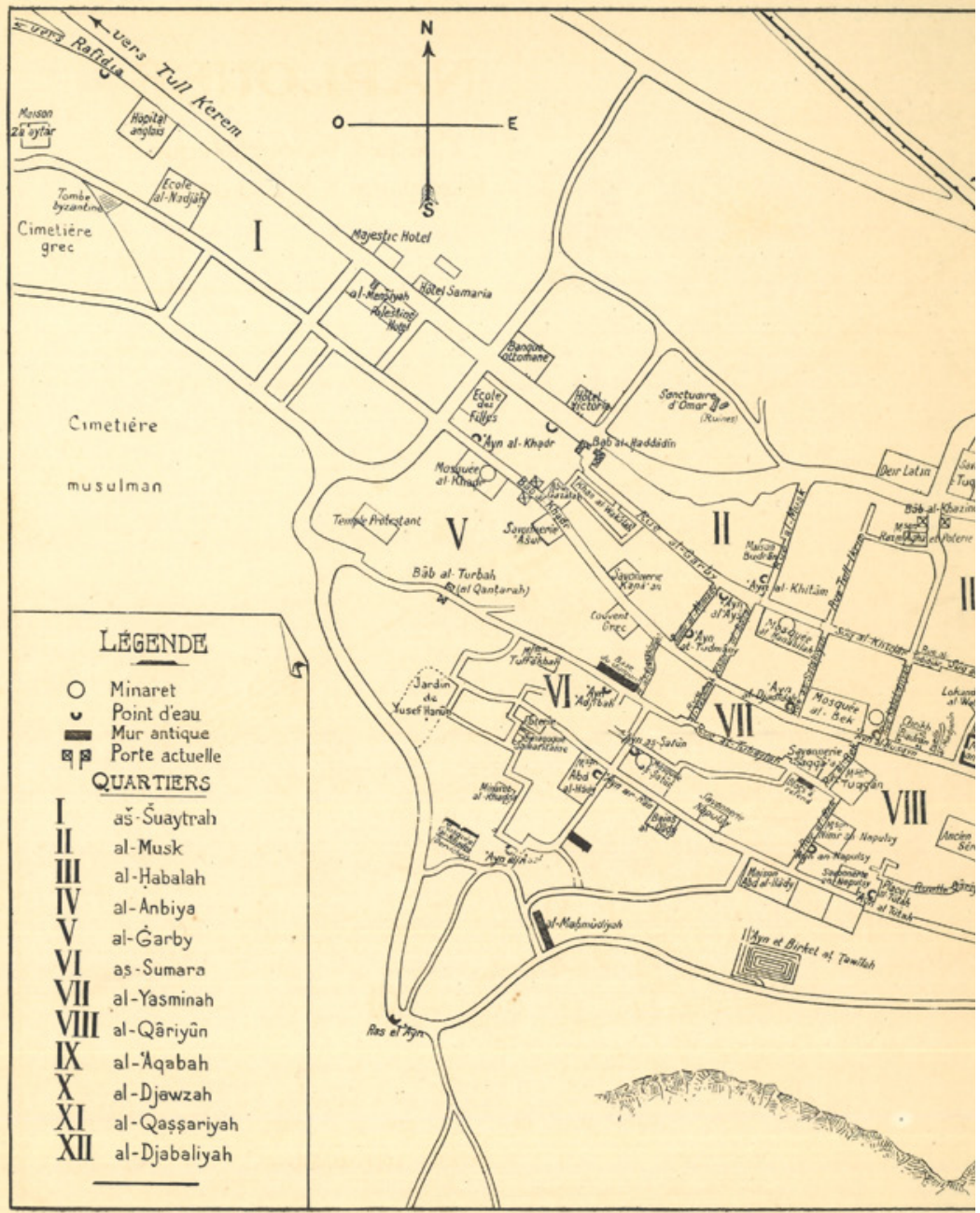

FIGURE 4.4 Plate IV Map of Nablus. Jaussen, Coutumes palestieniennes, 1927 


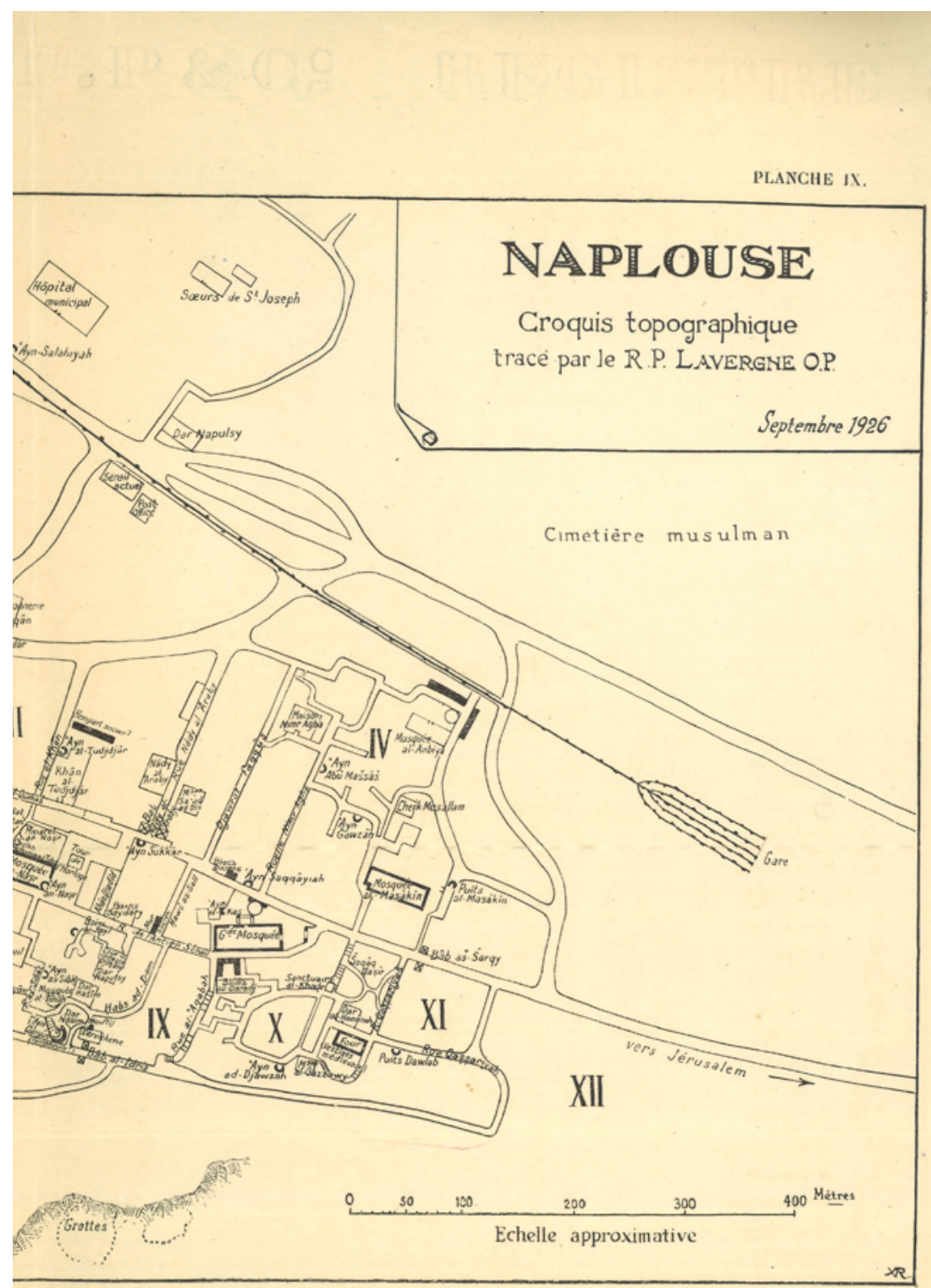


Nablusi families. Thanks to its commercial networks, the city was less landlocked than Jaussen announced in his introduction. Jaussen provides a map of the city before the 1927 earthquake (Fig. 4.4): it was divided into 12 districts, some residential, others reserved for economic activities such as trade, crafts and industry.

Yet, Jaussen chose to publish few photographs of the city itself in the book and insisted on depicting shrines and places of worship. If one chapter of the book is dedicated to professional activity, this is not reflected in the book's plates. Jaussen observed the suqs as a repository of traditional crafts and factories and not as singular urban or public space He decided to publish photographs of craftsmanship (Fig. 4.5), perhaps according to folklorist preoccupations as the activity would be considered as more authentic. In addition, if the monograph insists on the historical importance of the soap factories in Nablus and on the shared concerns of the city dwellers on the slowdown in activity after the war period, no picture echoes those thematics. Yet, the soap factory was emblematic of the economic and social life of Nablus and its region: agriculture with the olive oil production, industry with the factories, regional trade and the local history of notables' families. ${ }^{53}$

According to Jean Métral, Jaussen perceived Nablus as an exemplary traditional Islamic city. He presents Jaussen as follows: 'he is a Catholic, and seeks to understand in what way, and by what process, another religion, Islam, permeates the culture of the city dwellers and their day-to-day practices. ${ }^{54}$ This concern is not new to Jaussen. Coutumes des arabes au pays de Moab already included a long chapter on religion with a detailed description of sanctuaries, religious practices and beliefs. In Nablus, Jaussen takes up these themes which were also studied by some Palestinian folklore researchers of the time such as Tawfiq Kana'ān. ${ }^{55}$ The particularity of the study of Nablus lies within the theme of amulets and what Jaussen qualifies as magic. Here again, he takes up themes dear to Kanaān whose collection of amulets is conserved at the Birzeit University Museum. As Muslim reformism was developing and modernist thinking was flourishing, these endangered social practices were probably perceived as particularly significant of a changing world. For Jaussen, they seemed to be constitutive of the city's religious mode of belonging. Thus, in the book's plates he chose to depict a social world structured around shrines,

53 Véronique Bontemps, Ville et patrimoine en Palestine. Une ethnographie des savonneries de Naplouse (Paris: Karthala, 2012).

54 Métral, "Naplouse et son district: un essai de monographie urbaine," 133.

55 Tawfiq Canaan, Mohammedan Saints and Sanctuaries in Palestine (Jerusalem: Ariel Publishing House, 1927). 


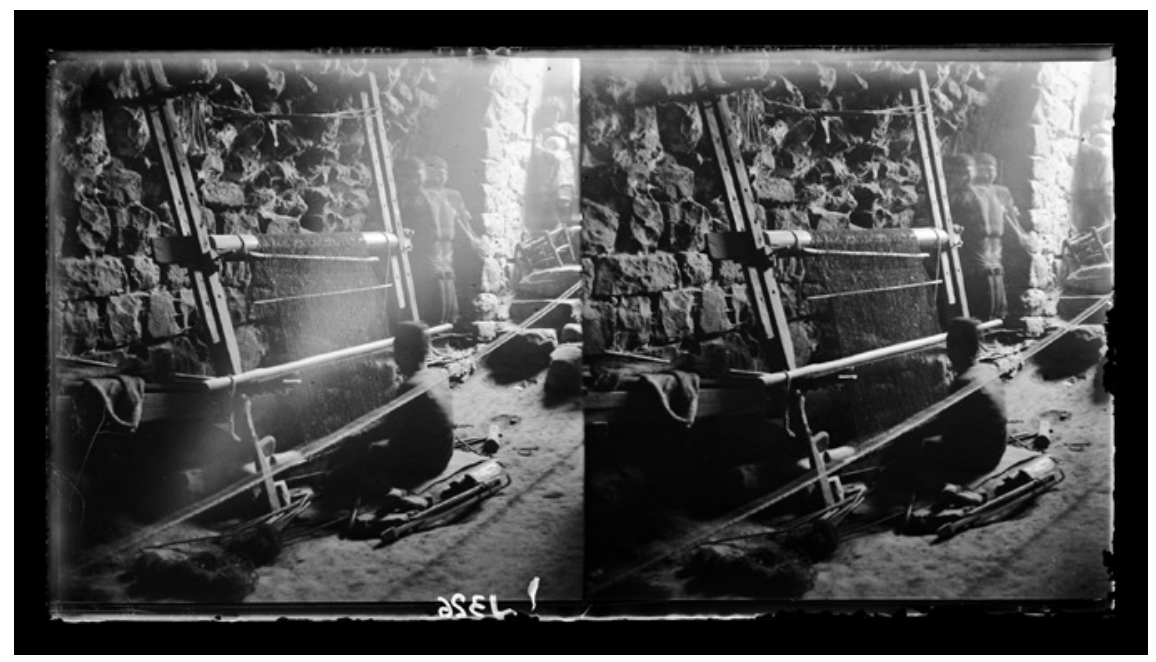

FIGURE 4.5 Nablus and its craftsmanship, the weaver, 1920s. Antonin Jaussen. Digitised glass plate, oo321-Jo326

IMAGE COURTESY OF EBAF

mostly located outside the city, sanctuaries and religious ceremonies. The photographs mostly represent buildings, without worshippers, clerics or guides (Fig. 4.6).

The unpublished photographs of Nablus mirror another social depth of the city and its inhabitants including: prayer in one of the city's mosques (Fig. 4.7), scenes from the daily life in the city's souks with men wearing the tarboosh (fez) (Fig. 4.8), the olive harvest in the city's surroundings (Fig. 4.9) and photographs of women. In these photographs, Jaussen also takes up more classic themes, such as the Samaritans, already represented by other photographers. Beyond Jaussen's bias in this monograph and its accompanying plates - depicting Nablus in its tradition and timelessness - the question arises as to the possibility of a visual ethnography at the time and its methodology, both ethical and material. Jaussen's photographs suggest a certain sensitivity in this regard as, for instance, in the picture representing the preparation of the qirāb (water bags) (Fig. 4.10). If using video and photography as a tool for anthropologists progressively became a concern from the 1970s onwards, in some of his photographs, Jaussen seems to have already, at least in some of his visual production, in the 1920's 'both implicitly and explicitly accepted the responsibility of making and preserving records of the vanishing customs and human being. ${ }^{56}$

56 Paul Hockings, Principles of Visual Anthropology, ed. World Anthropology Series (The Hague: Mouton; Chicago: Aldine, 1975). 
Coutumes Palestiniennes: Naplouse

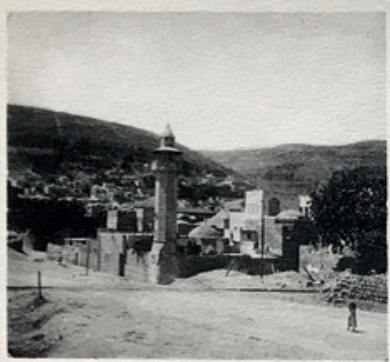

1. Djami‘ al-Anbiyâ.

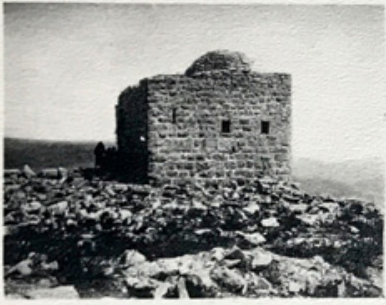

3. Le cheikh Ġânim.

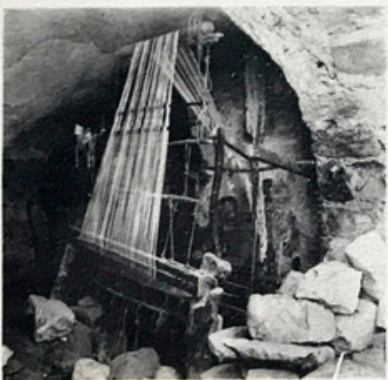

5. Métier de tisserand.
Planche VIII

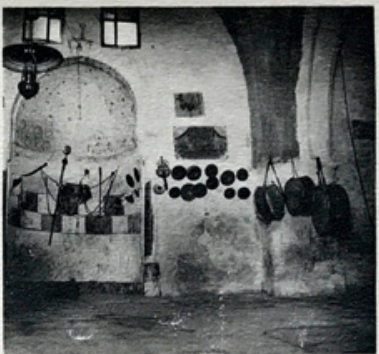

2. Cymbales et tambours..

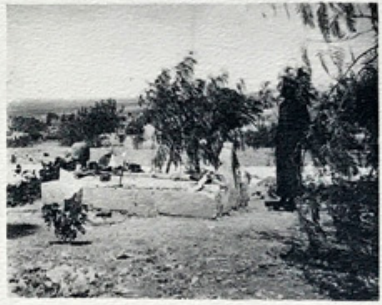

4. Le cheikh Abu'l-'adas.

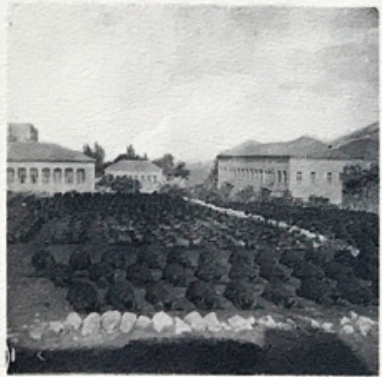

6. La préparation des qirâb.

FIGURE 4.6 Plate VIII, 1920s. Jaussen, Coutumes palestiniennes, 1927 


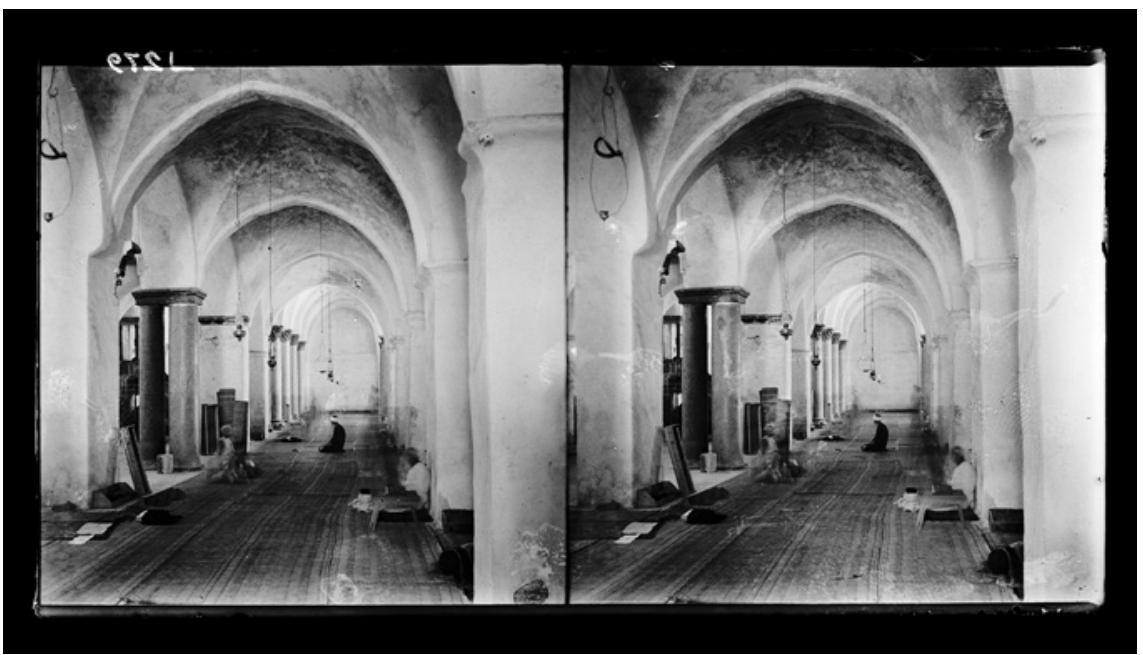

FIGURE 4.7 Prayer in one of the Nablus' mosques, 1920s. Antonin Jaussen. Digitised glass plate, 00274-Jo279

IMAGE COURTESY OF EBAF

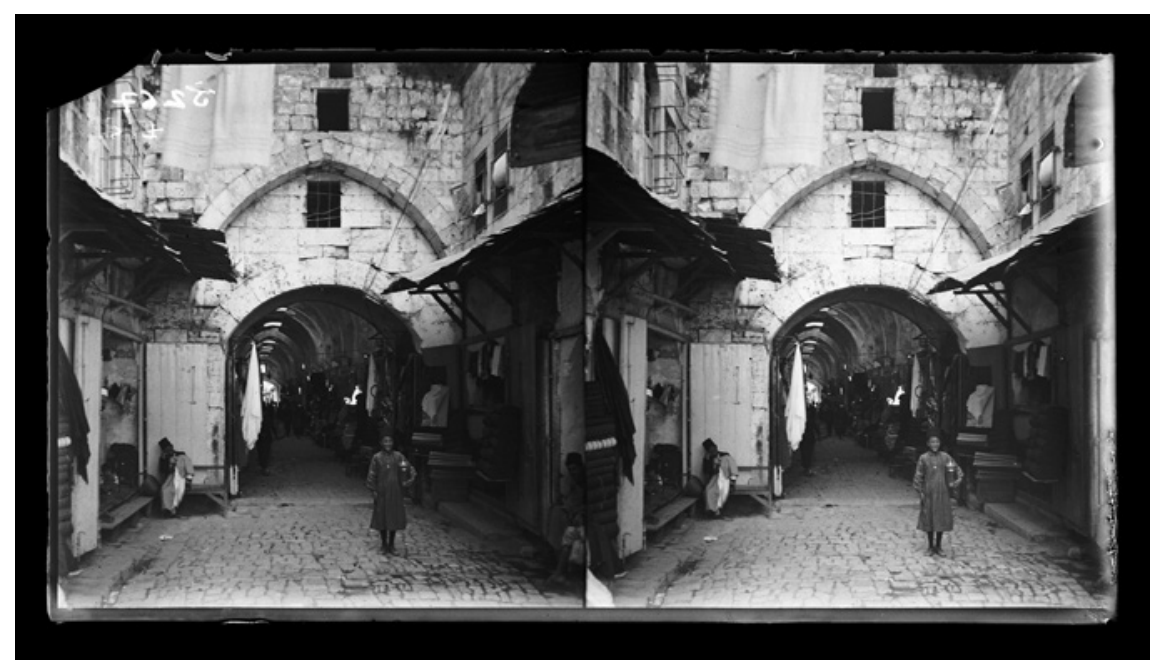

FIGURE 4.8 The suq of Nablus before the 1927 earthquake, 1920s. Antonin Jaussen. Digitised glass plate, o0262-Jo267 IMAGE COURTESY OF EBAF 


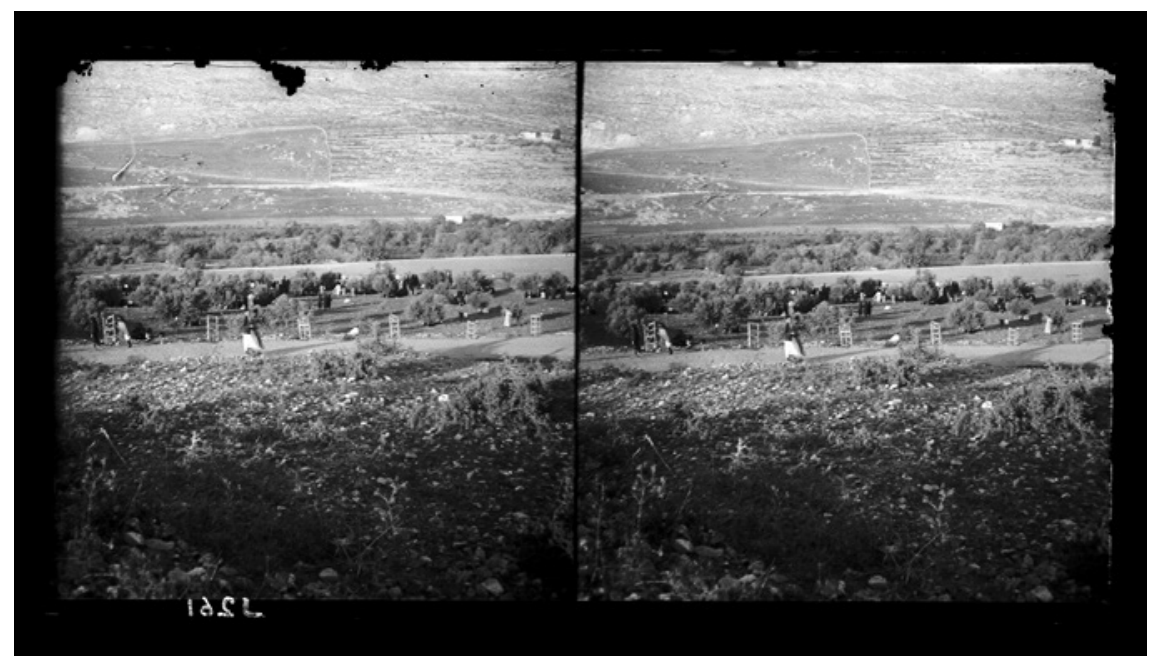

FIGURE 4.9 Olive harvest in the region of Nablus, 1920s. Antonin Jaussen. Digitised glass plate, oo256-Jo261

IMAGE COURTESY OF EBAF

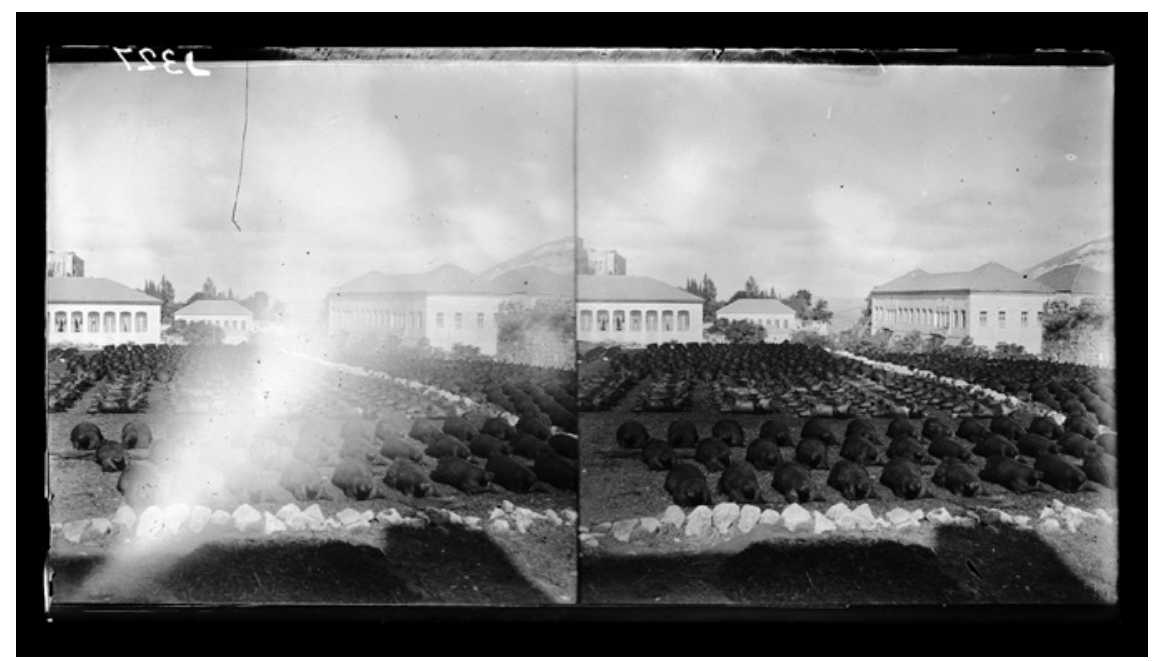

FIGURE 4.10 Preparation of the qirāb in Nablus, 1920s. Antonin Jaussen. Digitised glass plate, OO322-Jo327

IMAGE COURTESY OF EBAF 
These photographs, whether published or unpublished, are valuable sources since they document the state of the city before the earthquake of 1927. Jaussen's bias to depict a timeless city contrasts sharply with the series of photographs taken some fifteen years later, in 1940, by the American Colony that instead aimed at documenting the industrialisation of the city. ${ }^{57}$

\subsection{An Ethnography of Intimacy?}

In the study on Nablus, the place given to the study of women and women's sociability is noteworthy. Two chapters of the book are devoted to women (private and domestic lives), whereas this theme occupied only a sub-section of the book Coutumes des Arabes au pays de Moab. Jaussen explains this structure as follows: 'A woman is educated twice: the first time in her family, the second with her husband'. ${ }^{58}$ The study of Nablus devotes a significant part to urban intimacy and household life.

Jaussen analyses the social dynamics of the city through a gendered perspective. In his perspective, the public space is reserved for men and marked by buildings and equipment of power (seraglio and municipality); of trading, crafts and industry (the souks, the soap factories); the khans and the courts. 'The law of confinement and separation'59 limits the access of women to these public spaces. He qualifies the feminine city dwelling through the ritualisation of their mobility around some places such as the hammam, the cemetery or events such as weddings or gatherings around olive trees during the summer season. He also gives some descriptions of their ritualised urbanity ${ }^{60}$ and different forms of 'sociability' between women, through the description of parties and ceremonies. The book also deals with issues related to intimacy, female genital circumcision and sexuality.

How did Jaussen investigate women in Nablus, since he stipulated: 'It is difficult for a stranger to know the habits of Nablusi women who can never be questioned directly. The obstacle is even greater if the survey concerns intimate lifestyles'.61 Jaussen collected information during his surveys of Arab inscriptions in the city or at the St Joseph Sisters' dispensary. Part of the data also come from women's testimonials and interviews with Jaussen's privileged

57 See the series Arab factories \& gen[eral] improvements in Nablus, https://www.loc.gov/ item/2019711122/ttps://www.loc.gov/item/2019711122/.

58 Jaussen, Coutumes palestiniennes, 85 , 'La femme reçoit deux éducations: la première dans sa famille, la seconde chez son mari.'

59 Jaussen, Coutumes palestiniennes, 114.

6o Métral, "Naplouse et son district: un essai de monographie urbaine," 126.

61 Jaussen, Coutumes palestiniennes, 40. 
male interlocutors, in particular sheikhs. The latter potentially take up the fantasy projections of female socialisation by men in the city, but was an attempt to overcome the methodological limitations imposed by the fieldwork.

The photographic plates of the book echo the focus given to women. Female portraits were commonplace for photographers at the time. One thinks in particular of Bonfils' portrait of a woman from Nablus - very likely a model that posed - representing a young woman sitting, dressed for the occasion, the lower part of her face covered by a veil. Postcards ${ }^{62}$ and family portraits ${ }^{63}$ were also widely used to depict women, with different perspectives and objectives. In addition, colonial fantasies about the 'Oriental' harem are the result of the difficulties Europeans had in understanding female spaces in Islamic societies. ${ }^{64}$ The issue of the representation of women in the colonial context has been the subject of significant literature emphasising their eroticisation. In a context of growing nationalism, portraits of women have also contributed to national or activist iconographies, as in Egypt. ${ }^{65}$ What narrative do Jaussen's portraits of women carry?

The discrepancy between Jaussen's description of social dynamics and the portraits presented in the book's plates is insightful. He states:

The black veil (al-burqa') which, like a thick curtain, falls from the top of the head to the chest, completely obscures the view of the woman's features from the curious eye. Describing the physiognomy of a Nablus woman seems an impossible attempt for the visitor, who is necessarily kept at a distance. ${ }^{66}$

However, photographs of three women with uncovered faces within their house are reproduced in plate II (Fig. 4.11). On the lower right, a posed portrait of a woman obviously belonging to the Christian bourgeoisie of Nablus (Fig. 4.12). The composition of the picture recalls that of the wife of Ibrāhim al-Tuwāl, from Mādabā (Fig. 4.13), photographed by Savignac in 1905, especially

\footnotetext{
62 Annelies Moors, "From 'Women's Lib.' to 'Palestinian Women': The Politics of Picture Postcard in Palestine/Israel," in Visual Culture and Tourism, eds. David Crouch and Nina Lubbren (Oxford and New York: Berg Publishers, 2003), 23-39.

63 Nassar, "Familial Snapshots."

64 Jocelyne Dakhlia, "Entrées dérobées: l'historiographie du harem," Clio. Histoire, femmes et sociétés 9 (1999): 1-13, online available via http://journals.openedition.org/clio/282.

65 Beth Baron, Egypt as a Woman. Nationalism, gender and politics (Berkeley: University of California Press, 2005).

66 Jaussen, Coutumes palestiniennes, 270.
} 


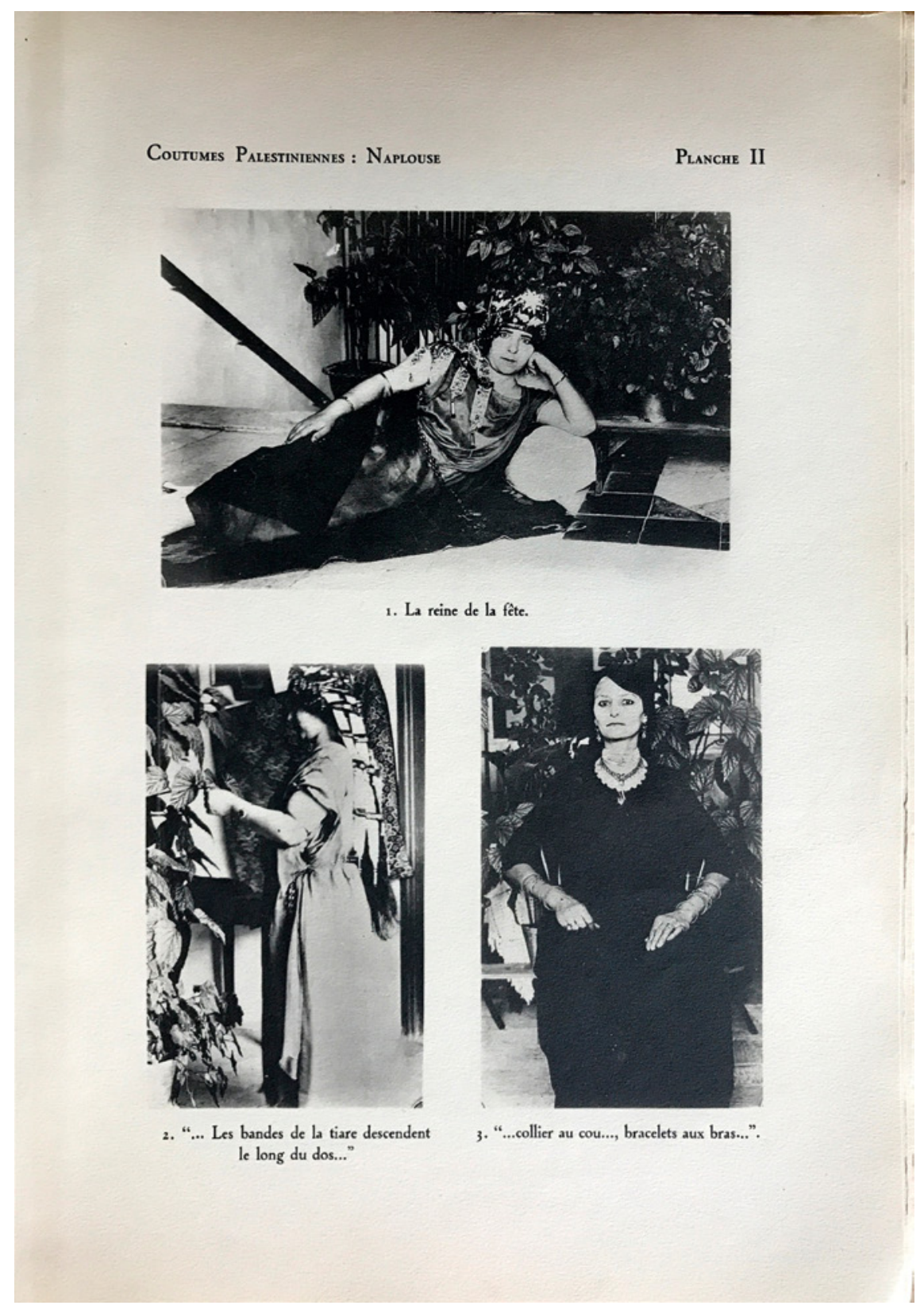

FIGURE 4.11 Plate II, 1920s. Jaussen, Coutumes palestiniennes, 1927 


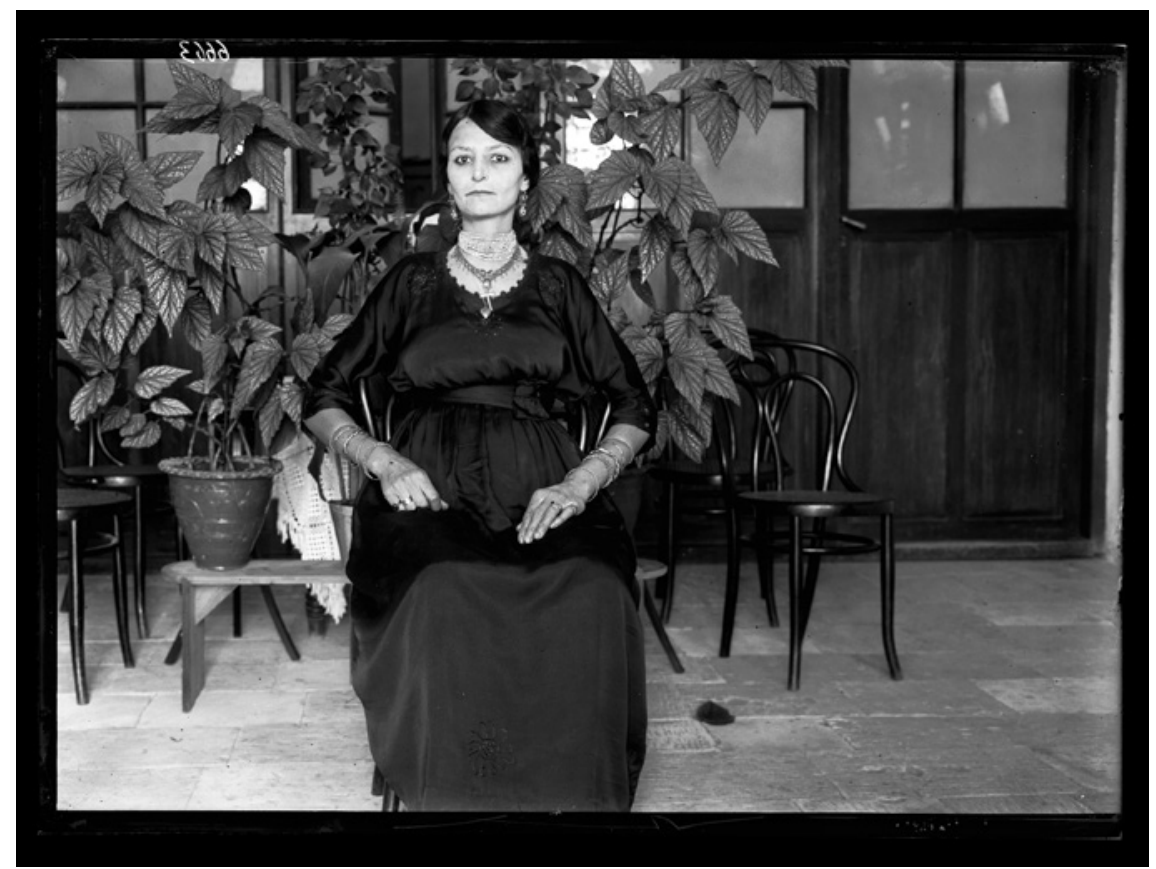

FIGURE 4.12 Christian Palestinian lady of Nablus, 1920s. Antonin Jaussen. Digitised glass plate, $11 \times 15 \mathrm{~cm}$, o030o-Jo305 IMAGE COURTESY OF EBAF

the disposition of the arms. Clearly, the purpose of the photograph is to depict the clothing and jewellery - which is carefully described in the book - but also the atmosphere within the house. It is more as a model and not as a subject-actor that this woman is represented in an almost folklorist perspective. This portrait does not reveal much exoticisation, but rather the valorisation of a certain urban bourgeoisie.

On the other two photographs of plate II, the folklorist interest in the materiality of womanhood also appears clearly with a focus on women's clothing and headdresses. All the pictures seem to have been taken in the same house. Moreover, for those two photographs and others unpublished (Fig. 4.14), the same woman poses to illustrate different situations. Probably confronted with the impossibility of taking portraits of women from various social backgrounds, Jaussen opted for, posed and composed portraits. This seems quite far from the intimacy of female sociability presented in the text. At the top of the page, the elongated portrait takes up the Orientalist codes of female representation (Fig. 4.15). The composition of the photograph recalls odalisque paintings. This 


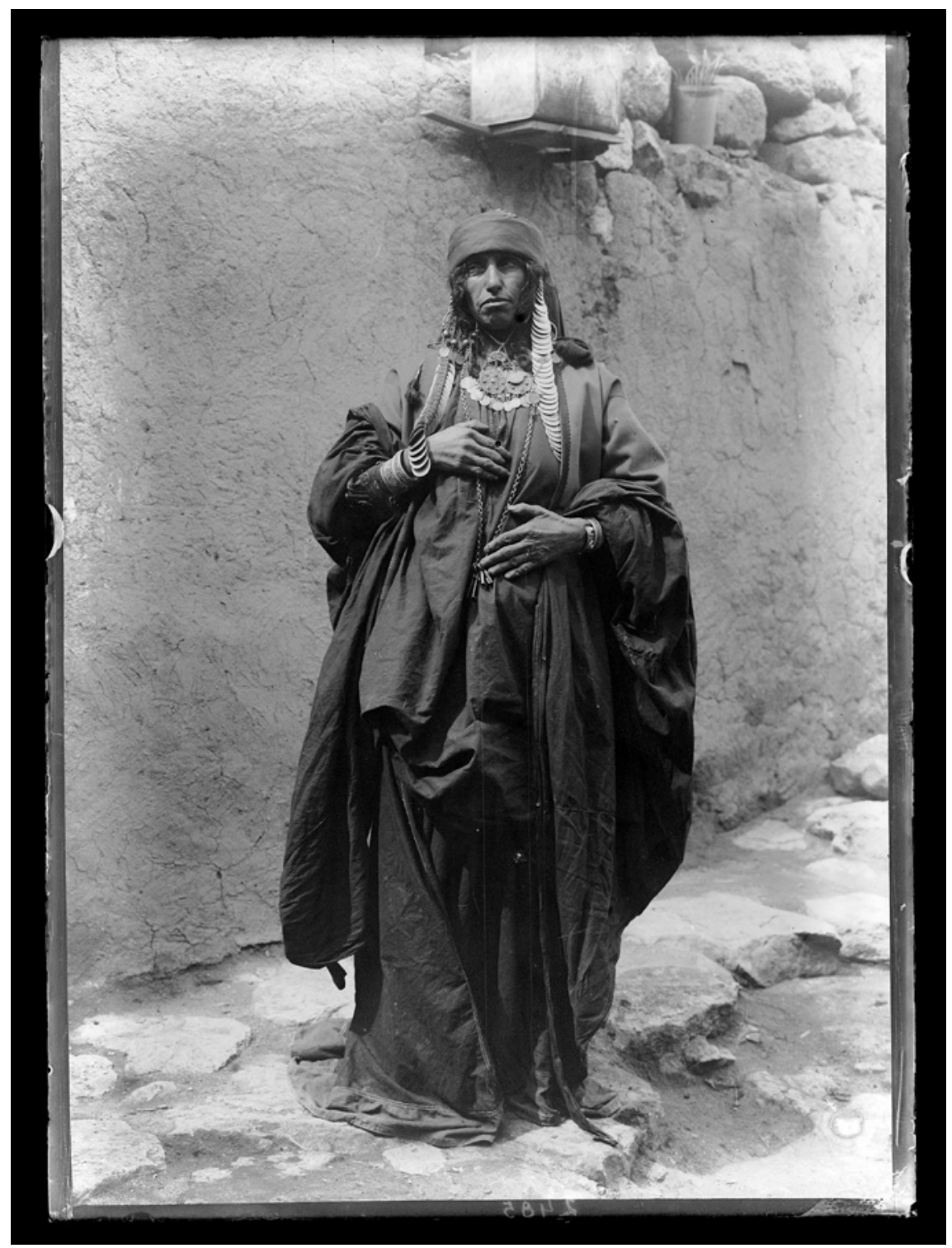

FIGURE 4.13 The wife of Ibrāhìm al-Tuwāl of Mādabā, c. 1905. Raphaël Savignac. Digitised glass plate, $11 \times 15 \mathrm{~cm}$, oO3OO-Jo3O5 IMAGE COURTESY OF EBAF 


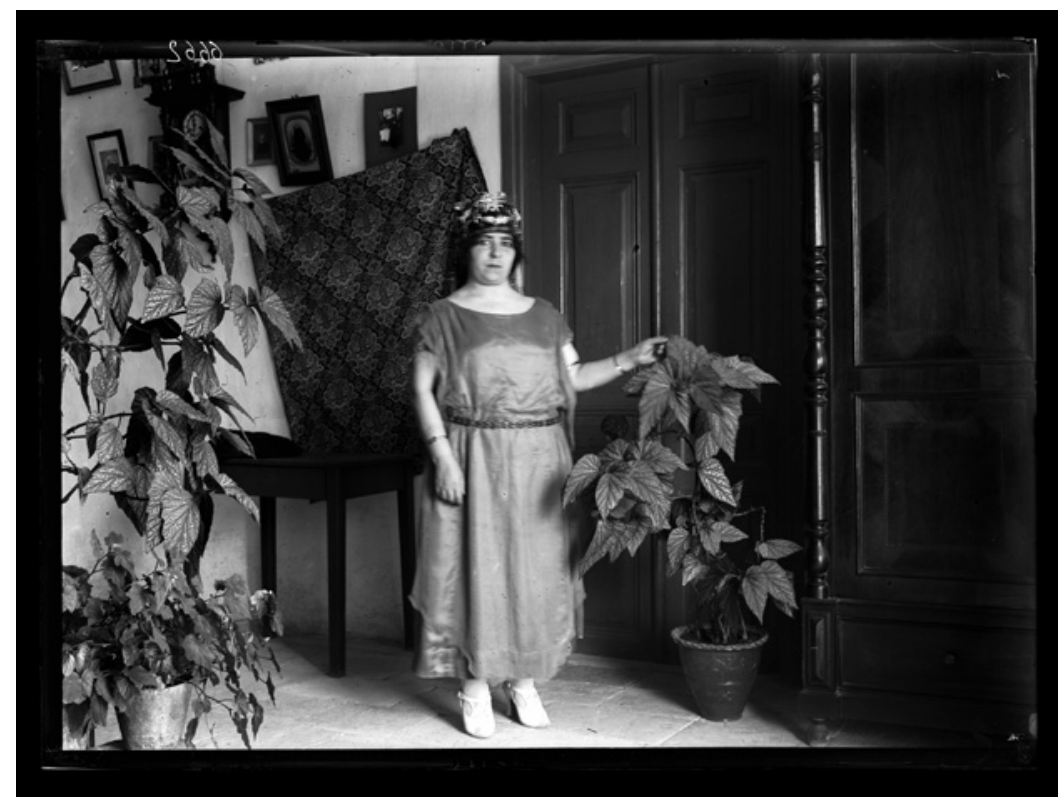

FIGURE 4.14 Portrait of a Nablusi woman, 1920s. Antonin Jaussen. Digitised glass plate, $11 \times 15 \mathrm{~cm}$, 003O2-Jo3O 7 IMAGE COURTESY OF EBAF

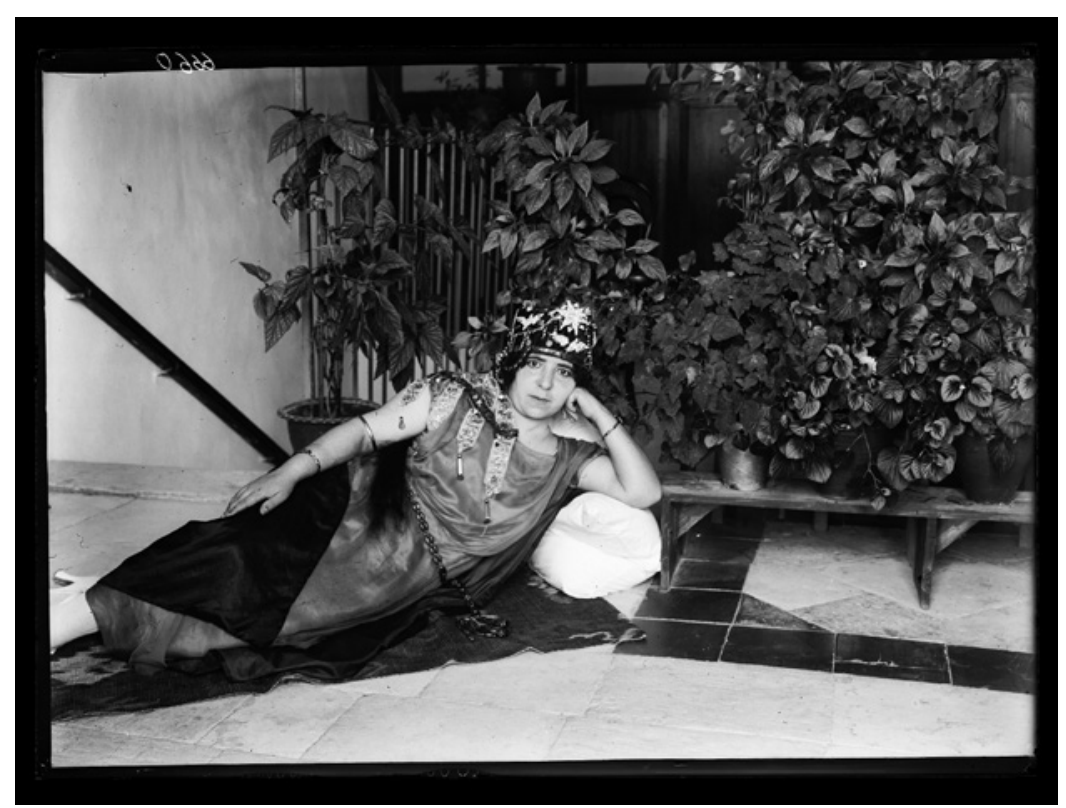

FIGURE 4.15 Portrait of a Nablusi woman lying down, 1920s. Antonin Jaussen.

Digitised glass plate, $11 \times 15 \mathrm{~cm}$, 00302-Jo308

IMAGE COURTESY OF EBAF 


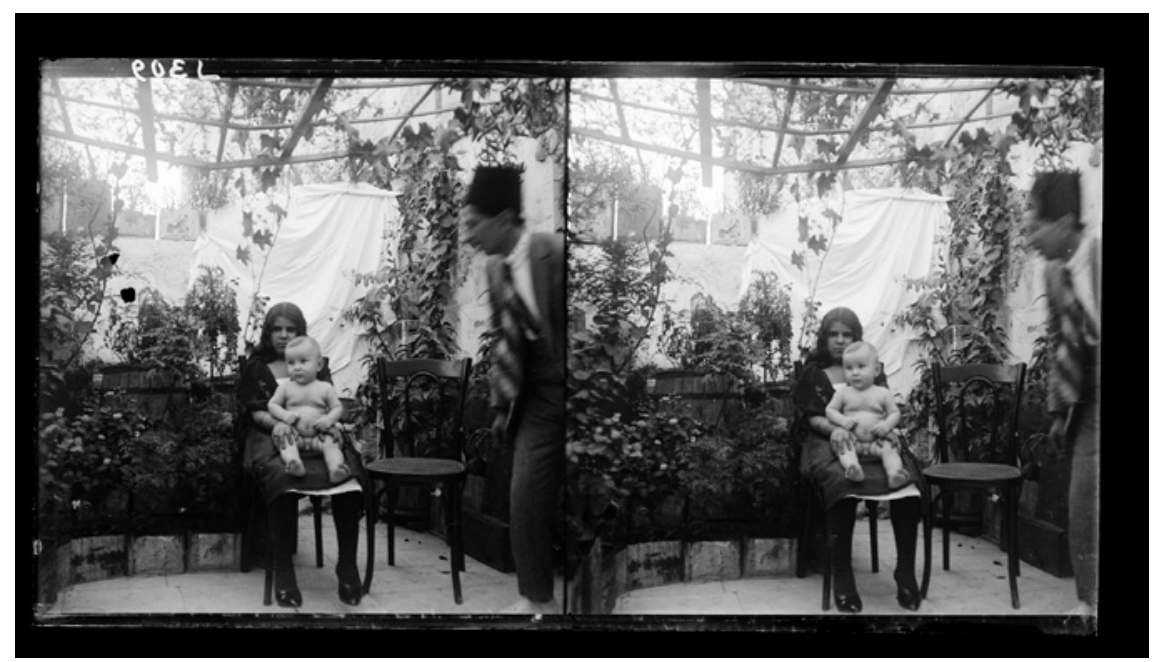

FIGURE 4.16 Nablusi woman with her baby on her knees, 1920s. Antonin Jaussen. Digitised glass plate, $11 \times 15 \mathrm{~cm}$, 00304-Jo309

IMAGE COURTESY OF EBAF

reveals that the circulation of harem iconography contributed to the creation of a historically distorted world in which gendered, staged images of anonymous models were attributed to Moorish, Bedouin, Jewish and Arab identities. The subject poses lying down, sideways on a makeshift bench installed on the floor. The photograph is taken near stairs, far from the intimacy of a bedroom or private room. It reveals the impregnation of an Orientalist imaginary and the methodological and technical inability to represent feminine intimacy differently.

For his book, Jaussen chose posed and highly composed photographs. Yet other pictures may show this feminine intimacy differently. For instance, one posed picture shows a woman with her baby on her knees. This representation echoes the symbolic universe and the canon of representation of the Virgin with the child and recall Biblical themes. (Fig. 4.16). Several photographs represent women visiting the Sisters' dispensary. In his book, Jaussen depicts women in what he projected to be the intimacy of their homes. To do so, in some respects, as experimenting with ethnographic portraits, he did not necessarily detach himself methodologically or artistically from Orientalist representations or other artistic codes. 
If Jaussen's photographs stand out within the EBAF's collection, they embody some of the scientific ambitions of this specific Catholic institution. How do we find, in the photographs of other Catholic institutions, concerns that a posteriori can be read as ethnographic? Along with a visual production directly linked to religious objects and events in the different European Catholic communities in Palestine, the EBAF photographic collection provides insights into the Arab Palestinian communities and invites us to reflect on the role of missionary photography within social history. As observers of political tensions and social change, the missionaries' lenses captured more than what was explicitly and deliberately religious in nature. What representations emerge from this collection?

\subsection{Catholic Missionary Photographs and the Social History of Palestine}

We returned to the diversity of missionary images often, during and after our stay at the EBAF, and asked ourselves what they conveyed; what types of relationships might be inferred or imagined between the photographer and the people in the photographs. For us, as historians, the visual archives of missions must be approached with the same critical scrutiny as any other organisational record. How do photographs taken by missionaries constitute a distinct category of information that can be used alongside the more familiar text-based materials?

We expected the corpus of photographs of the other Catholic missionaries to include 'Holy Land' sites, archaeology, transnational movements of pilgrims during the interwar period, views on different aspects of what was presented as modernity/modernisation propelled by empires. ${ }^{67}$ Many of the photographs in the Catholic missionary collections we consulted for this article deal with what could be described as the physical influence of the missionaries: roughly one third of the photographs depict school buildings, mission compounds, construction projects, dispensaries and hospitals; one third (mainly those of the EBAF) archaeological sites. The other third depicts spaces of religion (dealing with Western and local religious events in Palestine) and spaces of power (related to consulates, local Arab elites or linked to specific political events).

67 Mary Roberts and Jocelyn Hackforth-Jones, "Introduction: Visualizing Culture across the Edges of Empires," In Edges of Empire: Orientalism and Visual Culture, eds. Jocelyn Hackforth-Jones and Mary Roberts (Oxford: Blackwell Publishing, 2005), 1-19; Michelle Woodward, "Between Orientalist Clichés and Images of Modernization," History of Photography 27, no. 4 (2003): 363-374. 
The collections document the religious endeavours of the missionaries as they reflect their experiences and agenda. These archives record their views of communities and the religious and political environment of British Mandate Palestine. Missionaries had both religious and mundane reasons to take photographs: they were record keepers and, with the advent of photography, they began to use photography to compile a visual record of their activities. They became more sophisticated about the educational and fundraising potential of photography. They also kept detailed records and photographs for their hierarchy and for missionary events within their correspondence with the Vatican. As a consequence, most Catholic missionary orders keep their archives, where they have an accumulation of historical photographs, taken for a variety of purposes, and in various styles and levels of technical skill.

When dealing with missionary photographs, inevitably comes the question of the 'propaganda'68 discourse these photographs convey. As Anne Hugon pointed out, it would be necessary to 'recover the intention of the producer' and 'understand how these images were perceived', ${ }^{69}$ which is very often difficult to grasp. The photographs in various missionary journals reflect the changes affecting missionary work, especially in their relations with indigenous peoples. ${ }^{70}$ The 'transformative' photographs, i.e. those that reflect the changes that people have undergone in contact with missionaries, are recurrent. ${ }^{71} \mathrm{But}$

68 Jean Pirotte, "La mobilisation missionnaire, prototype des propagandes modernes," in $L a$ mission en textes et en images, ed. Christine Paisant (Paris: Karthala, 2004), 213; Christraud Geary, "Missionary photography: private and public readings," African Arts 24, no. 4 (1991): 48-59; Paul Jenkins, "On using historical missionary photographs in modern discussion," Le Fait Missionnaire 10 (2001): 71-87; Paul Jenkins, "Sources of unexpected light. Experiences with old mission photographs in research on overseas history," Jarhbuch für Europaische Uberseegeschichte 1 (2001): 157-167; Jack Thompson, "Xhosa missionaries to Malawi: Black Europeans or African Christians?," International Bulletin of Missionary Research 24, no. 4 (October 200o): 168-170; Jack Thompson, Light on Darkness?: Missionary Photography of Africa in the Nineteenth and Early Twentieth Centuries, Studies in the History of Christian Missions (Grand Rapids, MI: Wm. B. Eerdmans Publishing, 2012).

69 Anne Hugon, "Aspect de la propagande missionnaire," in Images et colonies. Nature, discours et influence de l'iconographie coloniale liée à la propagande coloniale et à la représentation des Africains et de l'Afrique en France, de 1920 aux Indépendances, eds. Pascal Blanchard and Armelle Chatelier (Paris: ACHAC et Syros, 1993), 77-84.

70 Françoise Raison-Jourde, "Image missionnaire française et propagande coloniale," in Images et colonies. Iconographie et propagande coloniale sur l'Afrique française de 1880 à 1962, eds. Nicolas Bancel, Pascal Blanchard and Laurent Gervereau (Nanterre: BDIC, 1993), 50-57; Judith Becker, Menschen - Bilder - Eine Welt: Ordnungen von Vielfalt in der religiösen Publizistik um 1900 (Veröffentlichungen des Instituts für Europäische Geschichte Mainz Beihefte, Band 118).

71 In a comparative perspective, we questioned the main differences between Protestant and Catholic missionaries' photographs for the Mandate and noticed the Protestant 
most of these Catholic missionaries' photographs were not intended for missionary journals. ${ }^{72}$

The acknowledged motive of the missionaries may have been to record their own evangelical activities, to inform their superiors and ensure continued public support from their home nations. However, some seem to have been curious about what happened around them, whether or not those objects and events were specifically religious. The result is that the themes illustrated by the pictures in these collections are not limited to photographs that display or validate the missionary agenda. These images help in capturing the broader developments of cultural, economic, political and technological transformation of societies. They also show the international platform that was Palestine and the dynamics of power between European countries and different Christian communities, the growing Arab Latin Catholic communities in Palestine, their traditional celebrations as well as their trans-regional links, particularly to Transjordan. ${ }^{73}$

Looking at missionaries as photographers questions situations of complicity/distancing/spontaneity in the photographs, though this is often difficult to tackle. It also questions the bodies in the photographs. Within the context of a renewed interest in photography as an object, source and method in anthropology since the 1990s, ${ }^{74}$ missionary photography was analysed within a colonial framework. It was approached via the anthropology of the body or even an anthropology of aesthetics/otherness developed by missionaries ${ }^{75}$ that made these colonised bodies meaningful (mainly in the context of Africa). In this article, we tried to question the straightforward documentation, the 'counterintuitive events, $[\ldots]$ scenes that go against common stereotypes' $[\ldots]$

missionary work in the school field for example, aimed mainly at enabling the formation of an indigenous clergy and a certain secular elite; images of the child and the nun are major figures used as metaphors for Protestant missionary work. Norbert Friedrich, Uwe Kaminsky, and Roland Löffler, eds., The Social Dimension of Christian Missions in the Middle East. Historical studies of the 19th and 2oth Centuries (Stuttgart: Franz Steiner Verlag, 2010).

72 'It would be a pity, of course, if analysis of missionary photography only concerns themselves with photographs as propaganda', Jenkins Paul, "The earliest generation of missionary photographers in West Africa: The portrayal of Indigenous people and culture," Visual Anthropology 7 (1994): 137.

73 De Tarragon, "Holy Land Pilgrimage through Historical Photography."

74 Gilbert Beaugé and Jean-Noël Pelen, eds., "Photographie, ethnographie, histoire. Présentation," Le monde alpin et rhodanien 2-4 (1995): 7-17; Emmanuel Garrigues, "Le savoir ethnographique de la photographie," L'Ethnographie 109, 87-1 (1991): 11-54.

75 Dahbia Abrous and Hélène Claudot-Hawad, Mimétisme des corps et conquêtes des âmes. Les photographies des Missionnaires d'Afrique (Kabylie, Aurès, Sahara) (Paris: Non-lieu, coll; Entre-Rives, 2017), 14. 
challenging 'taken-for-granted presuppositions and stimulat[ing] new ways of looking at social change. ${ }^{76}$

By the First World War, male and female Catholic mission agents had succeeded in establishing outposts wherever the influence of European countries had penetrated Palestine: in the main cities, but also in rural areas, reaching remote regions. They were significant non-Arab witnesses to events in those places. Some were alert observers of the political, social and economic transformations of the period, though these evolutions were not at the heart of their albums/photographic collections.

\subsection{What Representation of Palestinian Society and Its Evolution?}

There are more photographs dealing with indigenous people for the Mandate period than for the period from the EBAF's establishment in 1890 to the fall of the Ottoman Empire. Some photographers seem to have sought to document the daily lives and traditions of Palestinian Arabs, while others seem to have been more interested in the changes that the mission brought. Many pictures were taken in diverse places, from the neighbourhood of the EBAF to coastal cities and remote villages of Palestine. Those pictures - as ethnographic evidence - represent different social groups ${ }^{77}$ not only the employees of the EBAF and the workers on the archaeological sites. They also show a good knowledge of some of the elites, as explained above (Fig. 4.17), the quality glass plate used to photograph this couple indicates that they were close to Savignac). They document the diversity of the missionaries' activities, of the Arab population and different types of events. Those multiple lenses also interact with the multiple agendas of the photographers so as to constitute situated testimonies on the Palestinian society of the time. Here (Fig. 4.18), a Christian family from Mādabā visiting the Dominican Friars, in the courtyard of St Stephen convent, just before or after WWI, illustrating the mobility and the transregional exchanges in the zone up to the early $1920 s$.

We targeted a few subcategories from the many intended and unintended cultural impacts ${ }^{78}$ of the missions rooted in the early development of

76 Stanczak, Visual research methods Image Society and Representations, 83-120.

77 The First Century of Photography: Photography as History/ Historicizing Photography in Ottoman territories (1839-1939), workshop organized by Boğaziçi University Archives and Document Center, RCAC (Research Center for Anatolian Civilization), and IFEA (Institut Francais d'Études Anatoliennes), İstanbul and Aix Marseille University, LabExMed \& IDEMEC, 19-21 June 2018, https://anamed.ku.edu.tr/wp-content/uploads/2018/o8/The _First_Century_of_Photography_ANAMED-1.pdf.

78 Heather Sharkey, Unexpected Consequences of Christian Missions in the Middle East, Africa and South Asia (Syracuse: Syracuse University Press, 2013). 


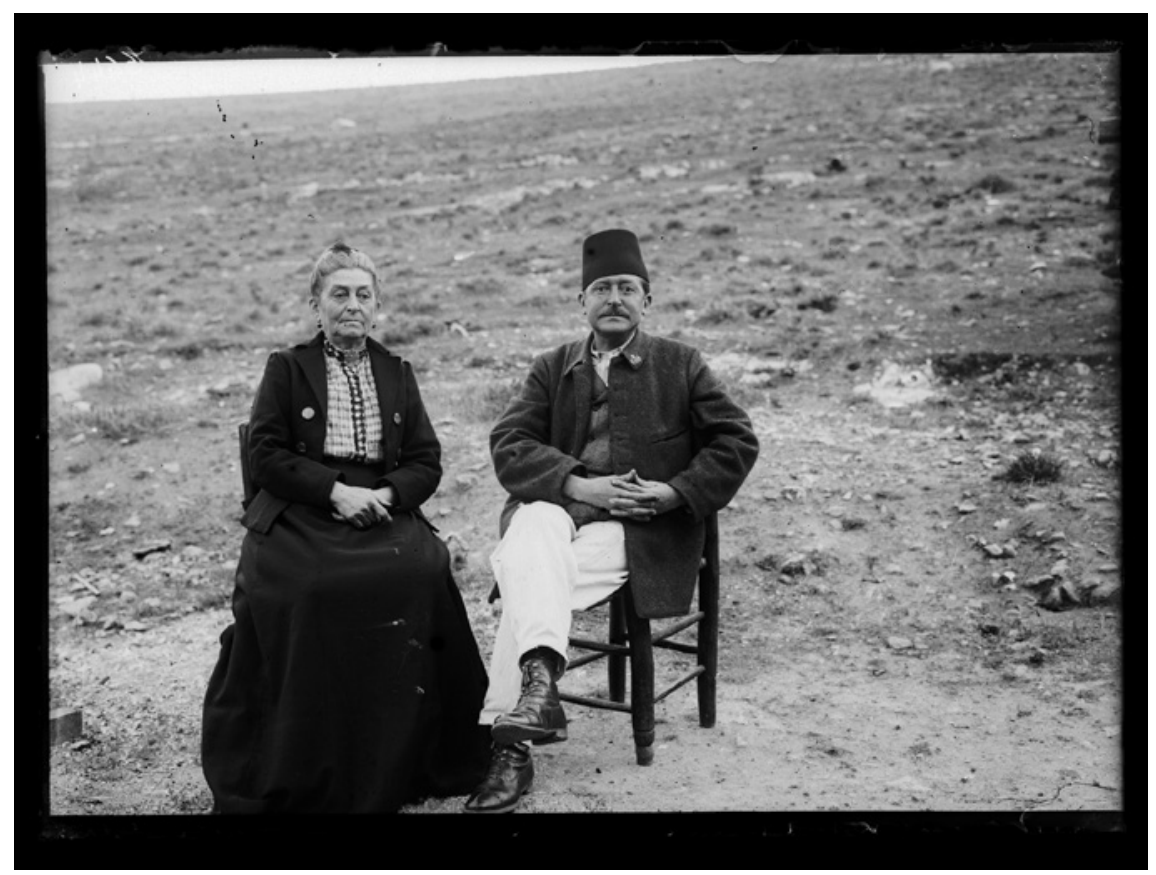

FIGURE 4.17 Couple levantin, after 1920. Raphaël Savignac. Digitised glass plate, $11 \times 15 \mathrm{~cm}$, 5601-6644

IMAGE COURTESY OF EBAF

missionary-founded congregations. They are by no means exhaustive or representative of the diversity of this collection.

The Dominicans commented on the political situation and were conscious of witnessing formative events for the Arab population. This is also true for some of the other Catholic missionaries. Though the Dominicans did not share the same time/space scales to Palestine as the indigenous Arab population. Jaussen was a witness of Arab frustration in Palestine during and after the First World War as evidenced in his reports to the French authorities. The silence about Zionist activities is remarkable. Jewish religious communities and celebrations do appear in the photographic collection, but not the Zionist associations, leaders or activities. This can be interpreted as a negation, either of their activities and impact in the missionaries' local environment at a proto-national level; or as situated outside missionary reality. Several missionaries did however reflect on the political events in different archives.

Indeed, during the political turmoil, missionaries were in the front row. For example, from the Old City of Jerusalem, where most Catholic missionaries had their compounds, they witnessed riots, curfews, their social and economic 


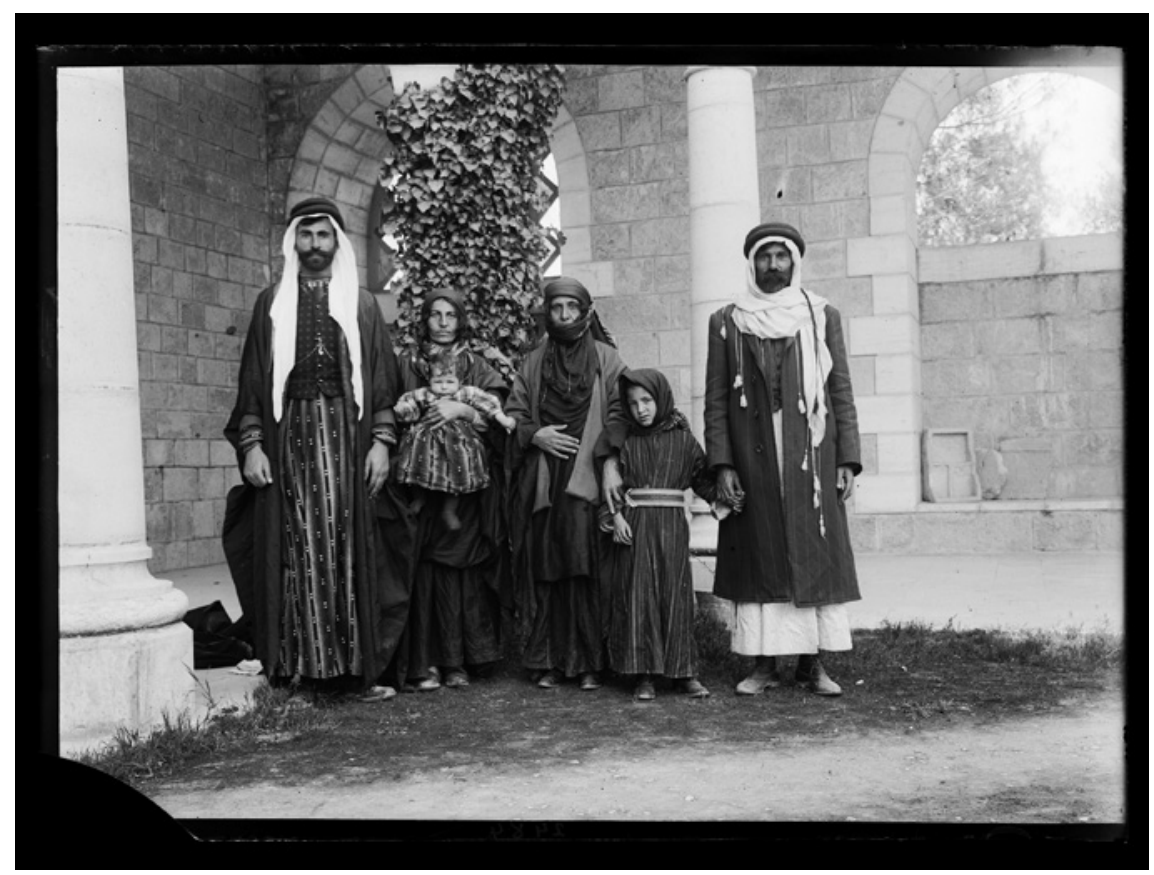

FIGURE 4.18 Catholic family of Mādabā visiting EBAF, early 1920s. Raphaël Savignac.

Digitised glass plate, $11 \times 15 \mathrm{~cm}, 5468-2484$

IMAGE COURTESY OF EBAF

impact. Cross-analysed with their diaries when available, the image of Jerusalem that emerges from this collection is not a sleeping city, resting on its mythical and biblical reputation during the Mandate, but a worldly and political Jerusalem. This might have resulted from the need to record and display Jerusalem, whether for specific religious audiences, or for French and Italian diplomats as well as for Vatican interlocutors. But also as a personal testimony, as confirmed in the diary entries of some missionaries. ${ }^{79}$ The following two photographs, likely taken spontaneously, most probably from the building of the Betharram Fathers in the Old City of Jerusalem, deal with the beginning of a riot on 13 th October $1933,{ }^{80}$ when the Arab Executive Committee planned a

79 Archives of the Collège des frères des écoles chrétiennes of Jerusalem ACJ, Bethlehem ACB and Caiffa (Haifa) ACH, Sisters of Zion diaries Asz, Archives of Saint Anne of Jerusalem diaries ASAJ.

8o The riots came as the culmination of Arab resentment at Jewish migration after it surged to new heights following the rise of Nazi Germany, and at the British Mandate authorities for allegedly facilitating Jewish land purchases. Rashid Khalidi, The Iron cage. The Story of the Palestinian Struggle for Statehood (Boston: Beacon Press, 2007), 32, 36. 
strike accompanied by a procession to take place from the Harām al-Ṣharîf to the Government Offices. The High Commissioner banned the demonstration, but it went ahead, regardless. British police officers stationed themselves at all the gates of the Old City and locked the gates to keep the rioters inside and dispersed them (Fig. 4.19 and Fig. 4.20).

Some photographs show other aspects of political events though not a priori dealing with them directly. The seminary of Saint Anne for the Melkites maintained by the White Fathers since $1882^{81}$ for example, has more than 200 photographs dealing with different political/religious events. The brass band of Saint Anne (fanfare) (Fig. 4.21), created in 1887, was requested by the Consulate General of France for notable events such as the Mass of 14 July (Bastille Day), the Mass of Joan of Arc or for the arrival of the first plane in Jerusalem on 31 December 1913. Different parts of Arab Palestinian society appear in this type of photograph. In this photograph of 1932, only the professor is French, Armand Laily. Saint Anne was also on the route followed by pilgrims during the celebrations of Nabī Mūsā, near the Harām and the Lions' Gate (Fig. 4.22, Fig. 4.23). During the Mandate period, the Mawsim al-Nabī Mūsā (the Prophet Moses festival), honouring the shrine of the Prophet Moses ( 7 kilometres from Jericho) was both a religious celebration and a national gathering for pilgrims from all Palestine. ${ }^{82}$ The riots during the Nabì Mūsā festival in Jerusalem in 1920 was an expression of opposition both to Zionism and to the British rule. These images were probably taken from one of the furthest rooms of the White Fathers' building on the Via Dolorosa. Several photographs concern Nabī Mūsā pilgrims in different parts of Jerusalem, during the different moments of the celebration. The photographer, a White Father, captured many moments while being among the crowd of pilgrims until the beginning of 1920, then more from Saint Anne's balconies (for instance in 1922; a British officer on horse, Fig. 4.22). The comments in the Saint Anne diaries and personal notes of some French Melkite Fathers reveal their understanding of the political repercussions and

81 Archives of Saint Anne of Jerusalem ASAJ, diaries of the junior and senior seminary, 1919 until 1933 and Central White Fathers archives, Rome, Saint Anne of Jerusalem reports, statistics and programmes of events. Dominique Trimbur, "Sainte Anne, lieu de mémoire et lieu de vie français à Jérusalem," Chrétiens et sociétés XVI ${ }^{e}-X X^{e}$, Bulletin 7 (2000): 39-69.

82 Awad Halabi, "Islamic Ritual and Palestinian Nationalism: al-Hajj Amin and the Prophet Moses Festival in Jerusalem, 1921 to 1936," in Jerusalem Interrupted:Modernity and Colonial Transformation 1917-Present, ed. Lena Jayyusi (Northampton, MA: Interlink Publishing, 2013), 139-161; Emma Aubin-Boltanski, Pèlerinages et nationalisme en Palestine. Prophètes, héros et ancêtres (Paris: EHEss, 2007); Roberto Mazza, "Transforming the Holy City: From Communal Clashes to Urban Violence, the Nebi Musa Riots 1920," in Urban Violence in the Middle East Changing Cityscapes: The Transition from Empire to Nation State, eds. Ulrike Freitag, Nelida Fuccaro, Claudia Ghrawi and Nora Lafi (New York: Bergham, 2015), 179-94. 


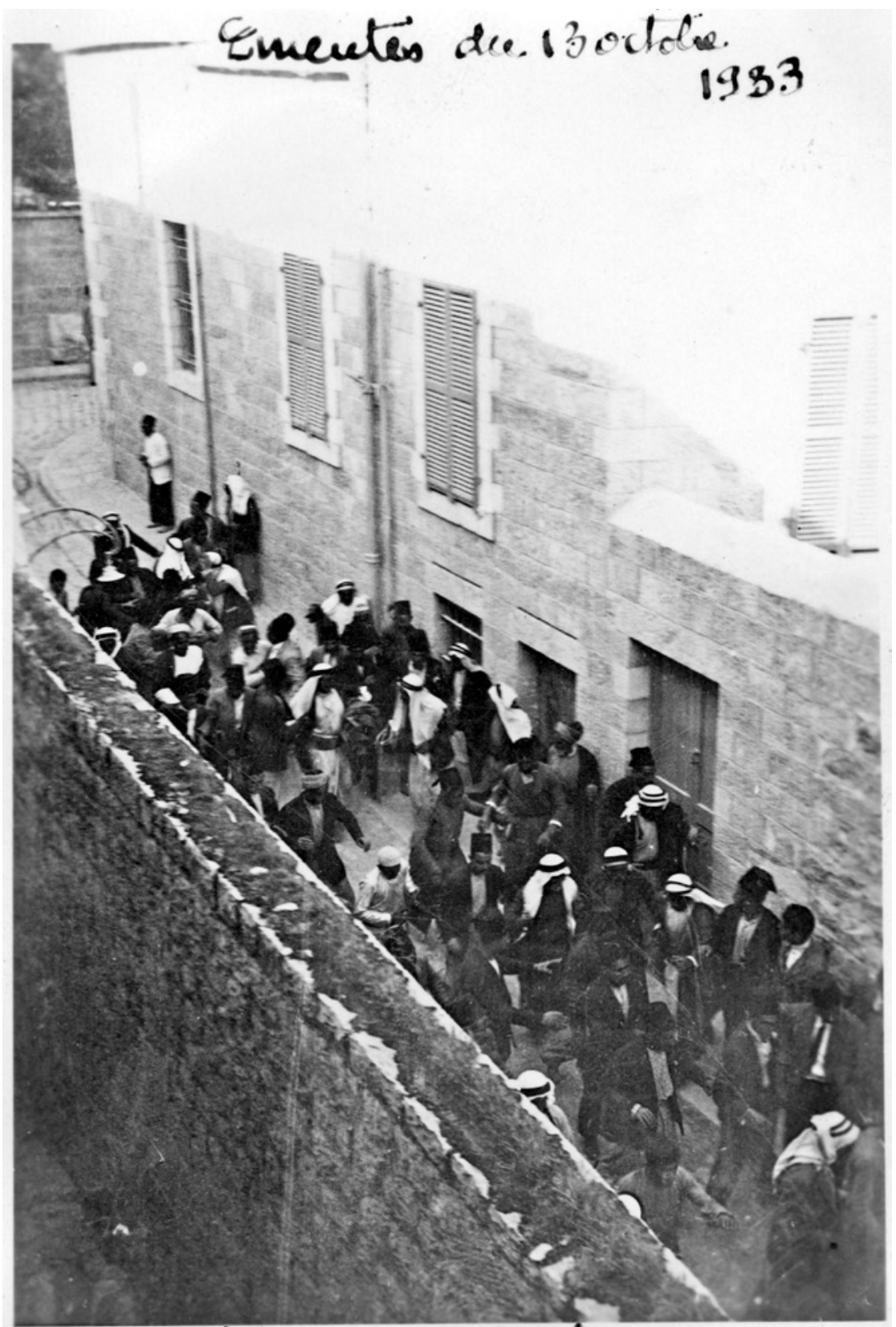

\section{Arsuct: is police aftroche...}

FIGURE 4.19 Riot, 13th October 1933. Caption (in French) on the top part: "Émeutes du 13 octobre 1933", bottom: "Avant: la police approche ..." Betharram Fathers, Médebielle collection; 22547-LPJ, 1644 IMAGE COURTESY OF EBAF 


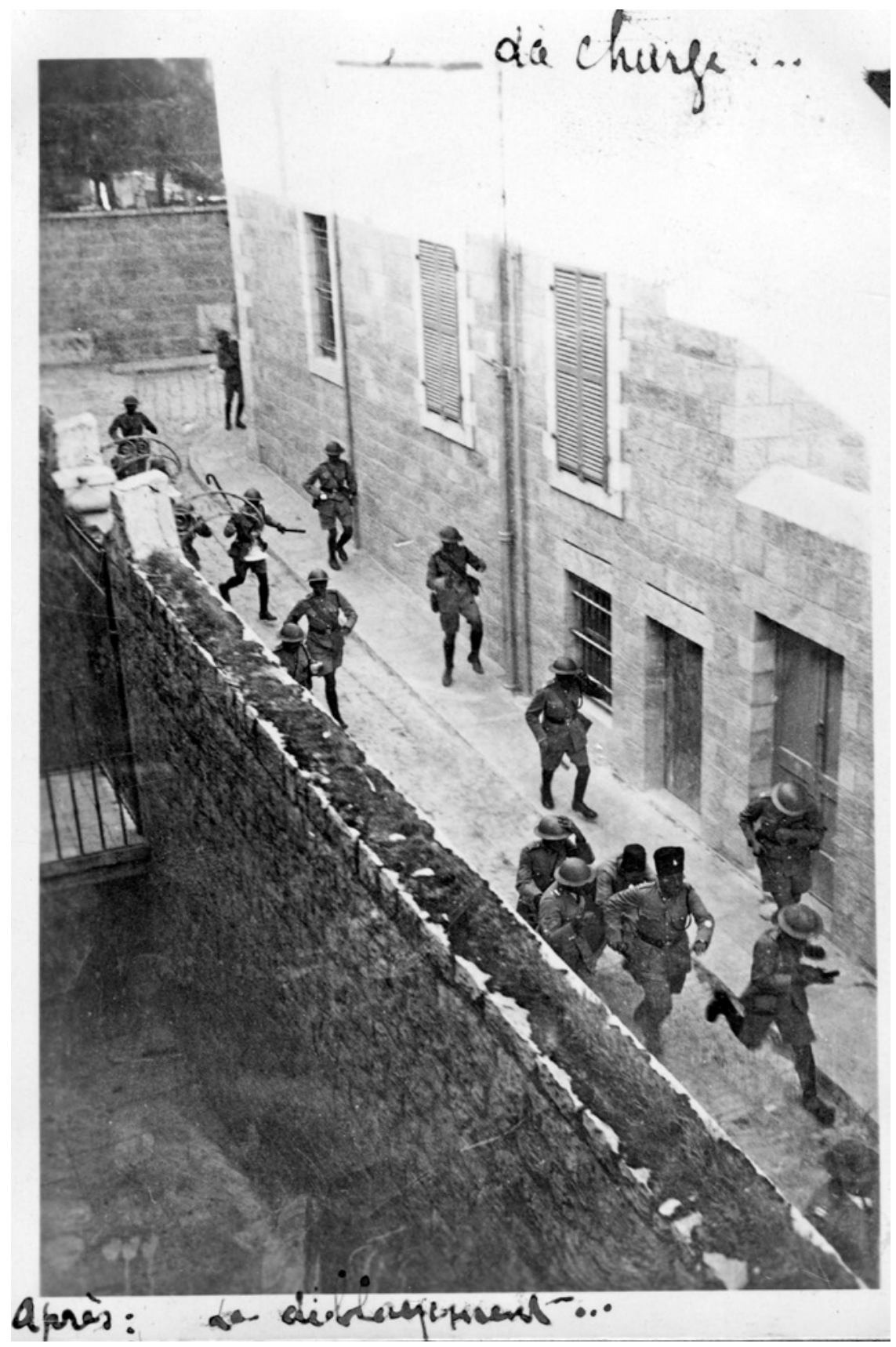

FIGURE 4.20 Riot, 13th October 1933. Caption on the top part: "La charge ..." bottom: "Après: le débloquement ..." Betharram Fathers, Médebielle collection; 22547LPJ, 1645 IMAGE COURTESY OF EBAF 


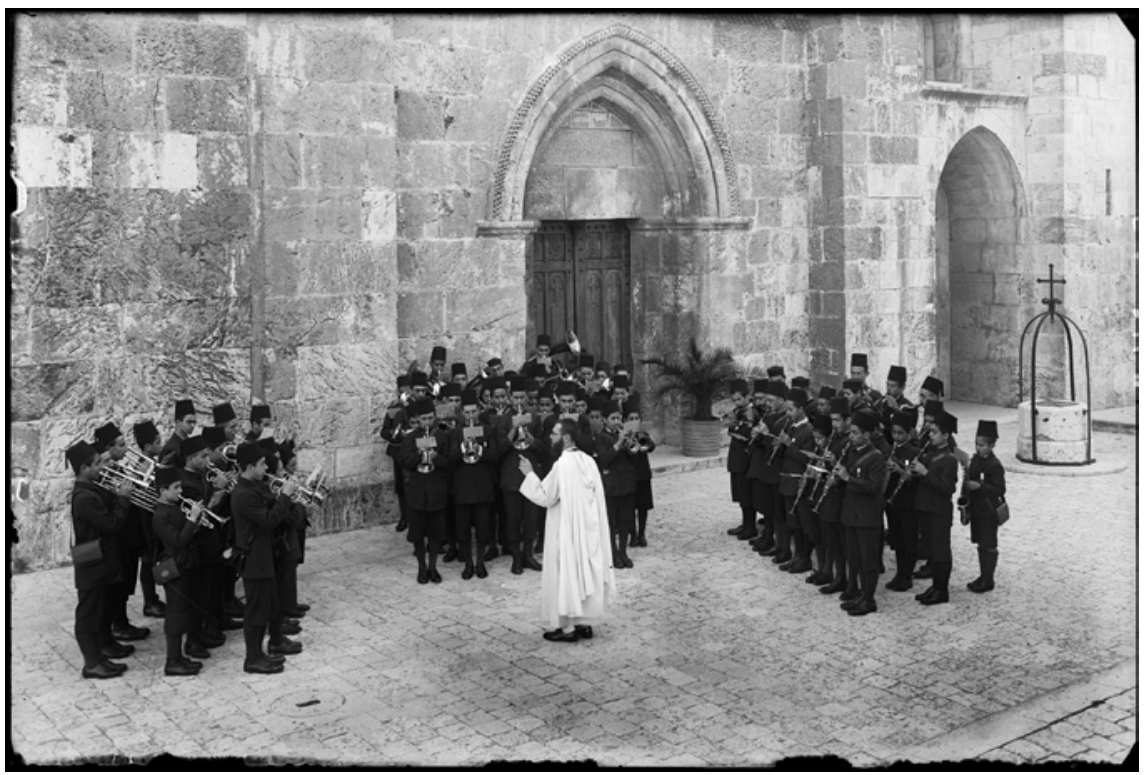

FIGURE 4.21 Brass band of Saint Anne (fanfare), early 1920s. White Fathers collection, 15977-SteA-0146

IMAGE COURTESY OF EBAF

the nationalist nature of this pilgrimage. They discuss the diversity of its participants (from Arab peasants to young nationalist activists) and the rivalry between the Husaynīs and the Nashāshībīs.

Several photographs concern the Arab clergy, its role within the different Oriental Churches, the cultural and religious influence around them and the ecclesiastical relationships between European missionaries and indigenous church members. Some photographs bring to the fore simple congregants, like in this photograph (Fig. 4.24) of a Melkite priest and his wife with their two daughters (until the 1920s they were not dressed in the Western style). The Saint Anne collection also addresses the rural Melkite communities. The following photograph of Nīcūlā Dāhbār (Fig. 4.25), a future Melkite priest and his father, taken in the garden of Saint Anne, at the beginning of the 1920s, is interesting on different levels. Dāhbār attended the Senior Seminary. He had already received minor orders (deacon in 1916) as he is wearing the Greek cassock and the cylindrical hat (without the edges at the top reserved for priests). Born in 1891 in Yabrūd (Syria, near Hums), he stayed twice at Saint Anne's because of the 1914-1918 war. In 1904 he arrived there as a junior seminarian at the age of 13; he remained there until 1914. During the war he taught in Damascus and returned to Saint Anne's, after the armistice. He was ordained in 1920. Friars 


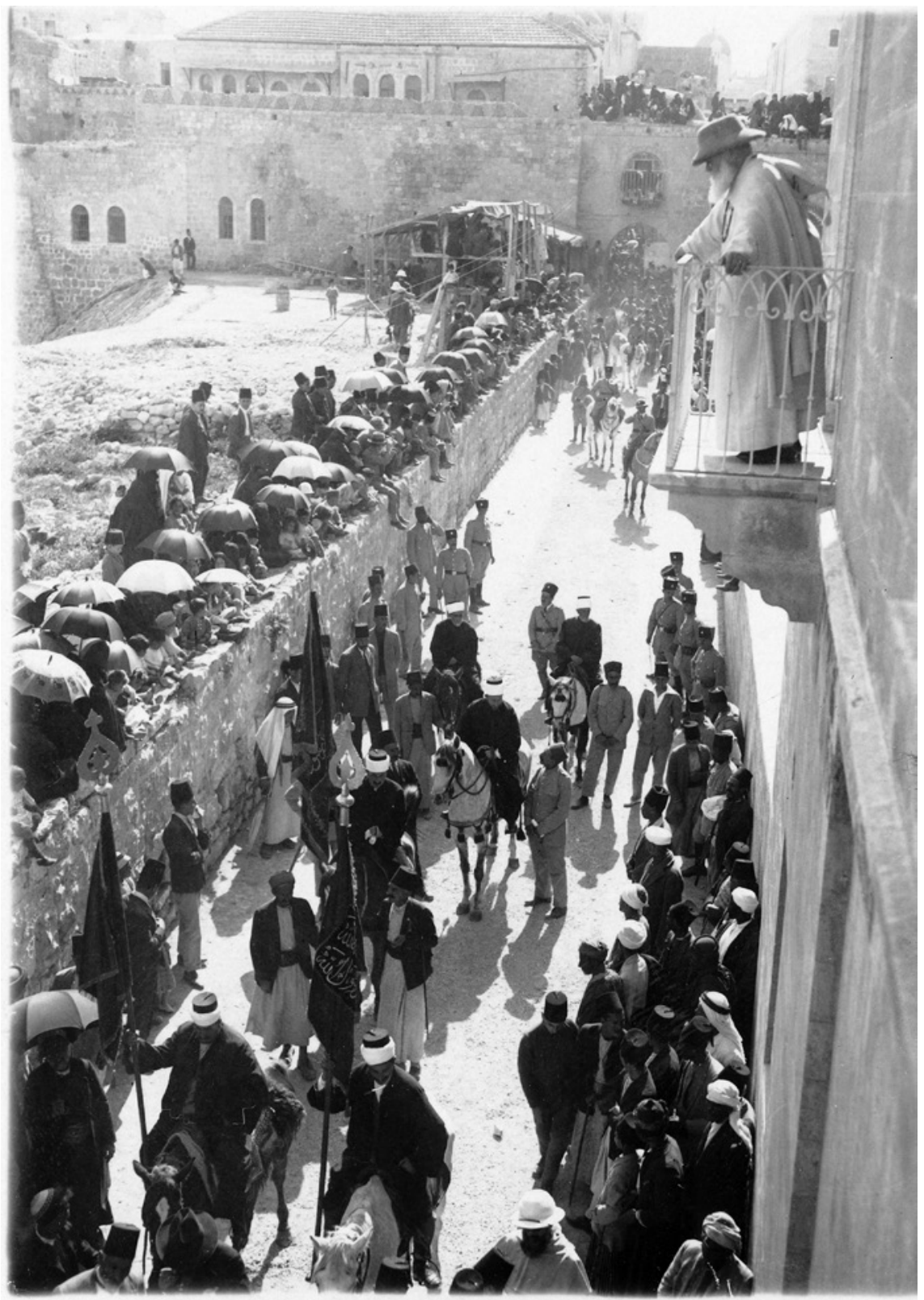

FIGURE 4.22 Nabi Mouça (sic) festival, 1922. White Fathers collection, 19348-Ste A-Cont.1275 IMAGE COURTESY OF EBAF 


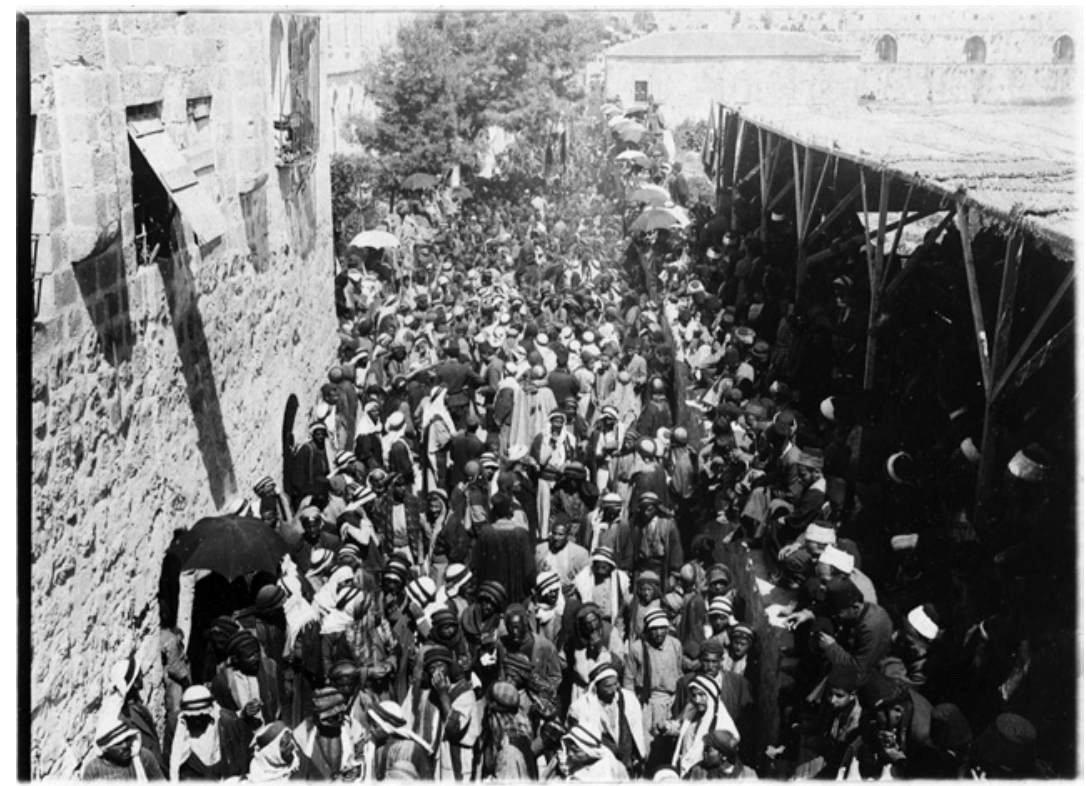

FIGURE 4.23 Nabi Mouça (sic) festival, 1922. White Fathers collection, Nabī Mūsā 19355-Ste A-Cont.1282

IMAGE COURTESY OF EBAF

wore the traditional dress of the cities and urban periphery. ${ }^{83}$ Later on, Dāhbār played an important role in the quarrels with the Bishop concerning the impact of French diplomacy and language on the Melkite communities.

Education was one of the means of social progression in Palestine; missionaries had been very active in this field since the last quarter of the nineteenth century. The photographic collections deal with different types of education provided for different groups, from the growing Arab Palestinian middle class to vocational education like that of the Salesian schools (Fig. 4.26). The Salesians maintained vocational schools mainly oriented towards agriculture, but also other manual trades according to the tradition they had inherited from Don Bosco. Initially created for orphans they rapidly admitted non-orphan children. The vocational schools welcomed children beyond the borders of Mandate Palestine. For the agriculture section, they recruited throughout the region. As in the case of the Melkite photographic collection, they show trans-regional relationships. The estate of Bayt Jamāl owned vineyards, had

83 Réseau Barnabé, "Regards sur l'éducation chez les Chrétiens d'Orient, A travers le fonds photographique ancien (1890-1930) de l'Ecole biblique et archéologique française de Jérusalem," 68. 


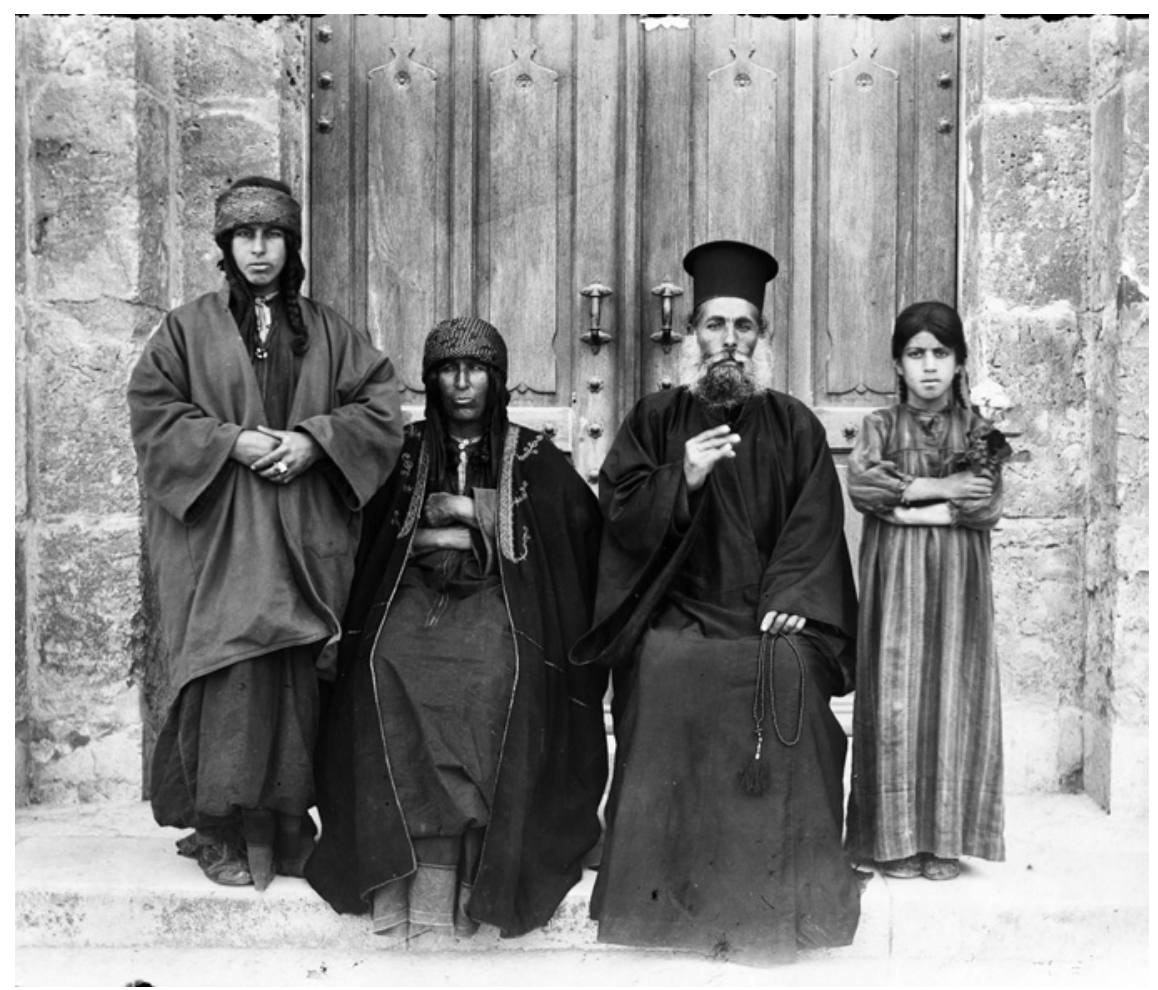

FIGURE 4.24 A melkite priest with his wife and daughters, 1920s. F. Jules Riffier, photographer of Saint Anne until 1926, White Fathers collection, from, 18325 Ste A 238 IMAGE COURTESY OF EBAF

developed the production of wine, and taught their pupils how to make good wine. The technical equipment and knowledge also echoes the Zionist equipment in agricultural outposts (here, a Fordson tractor with metallic wheels, in a region where harvest was difficult due to the stones).

Within missionary stations, students are mainly presented through classroom portraits, where they are organised in successive rows according to their gender. From the 1940s onwards, this aesthetic tends to disappear in favour of interactions between missionaries and Arab Palestinians. Schoolchildren are always photographed outdoors, but more often in less organised groups, with photographs taken 'on the spot'. In the class photographs for example, one perceives situations of collusion, spontaneous exchanges, the type of relationships that texts addressed to superiors do not always evoke (Fig. 4.27). Multiple influences on the Arab Palestinian population are revealed by clichéd gestures or practices. Appearances show the complexity of the influences: adoption of another costume, abandonment of local clothing with a strong symbolic charge (such as the tarbush). The 1930s also present the student's cultural activities, 


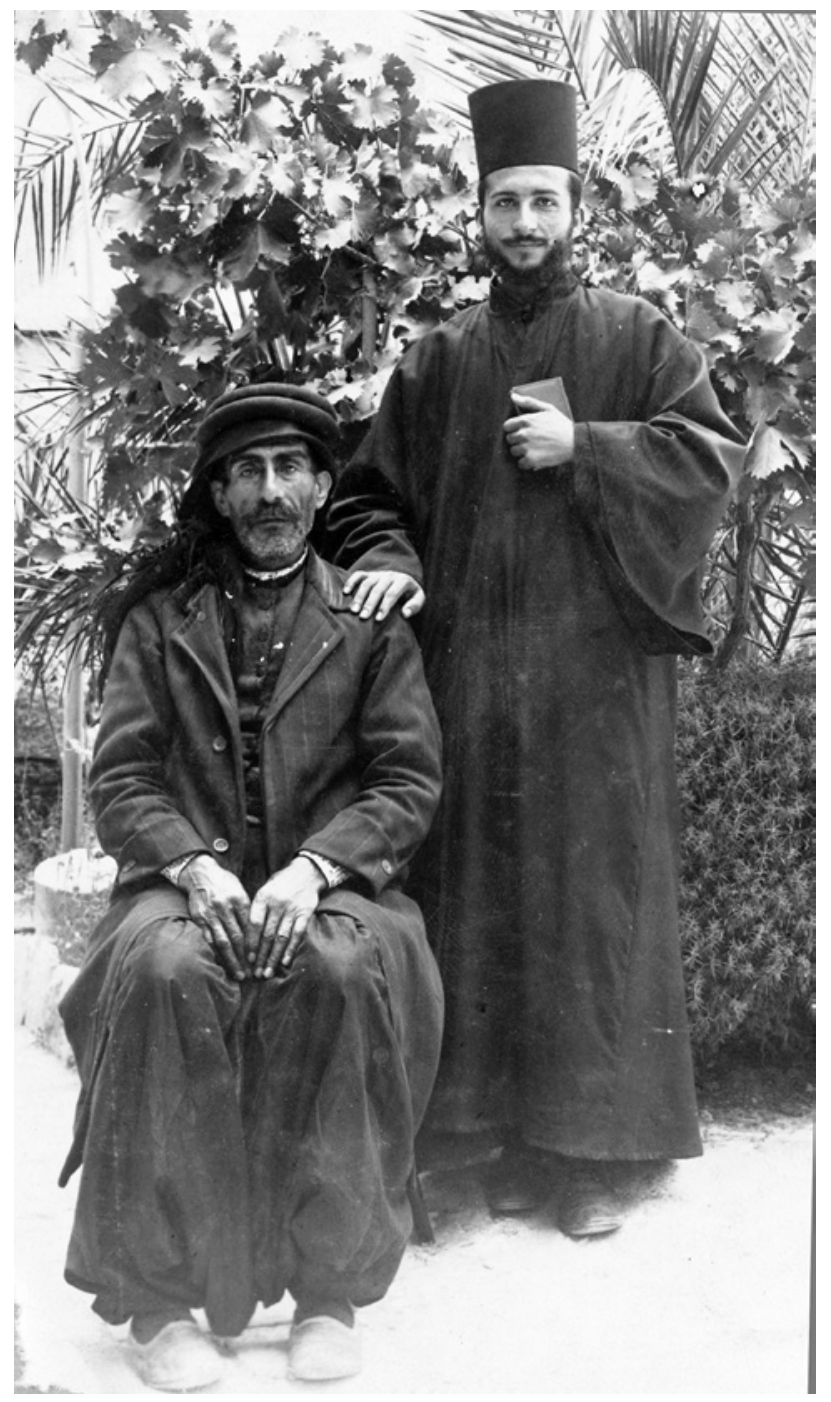

FIGURE 4.25

Nìcūlà Dāhbār and his father from Yabroud, 1920s. White Fathers collection, 18291-Ste A-Cont.2O4 IMAGE COURTESY OF EBAF

places of sociability and events in which Scouts participated in the competitive educational arena, (Fig. 4.28) offering cultural activities for youth. Catholic institutions competed the establishment of the YMCA with its multiple activities. The photographs also reveal the travels of pupils around Palestine and a comprehension of the 'national' 84 and religious heritage (no captions, but

84 Though the Catholic hierarchy prevented missionaries from taking part in local national agenda (Apostolical Letter Maximum Illud in 1919 and Encyclic Rerum Ecclesiae in 1926), the Latin Patriarch Barlassina, pro-Italian, emphasised the importance of the teaching of 


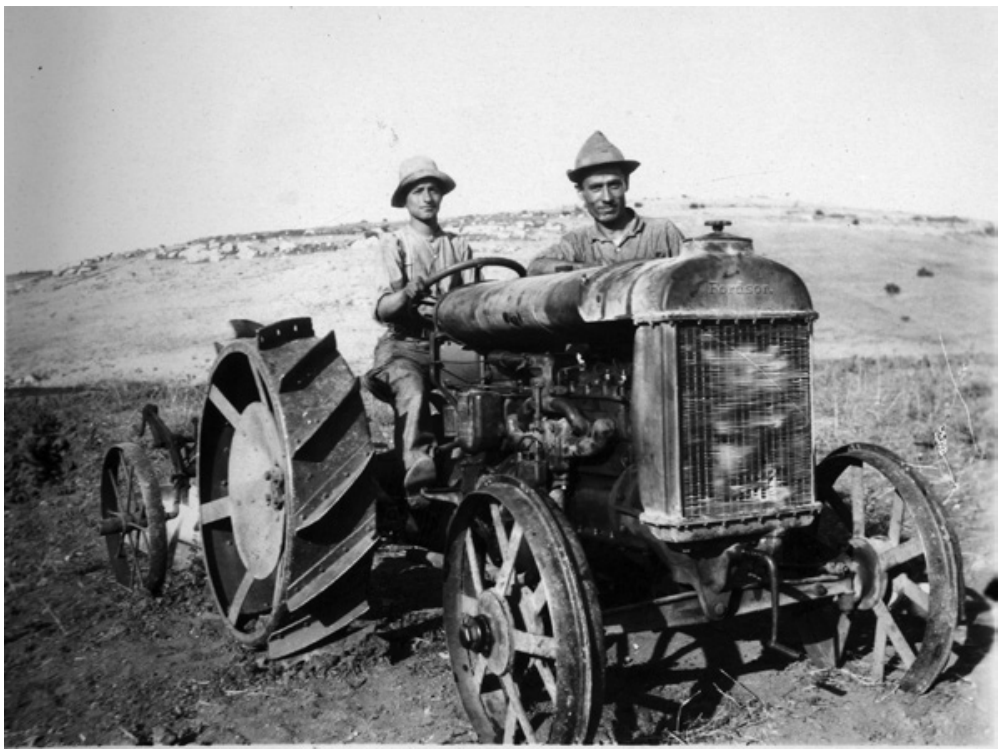

FIGURE 4.26 Salesian school, tractor Fordson, 1938. Collection of the Salesians Fathers, 17165-Sal.196, Beit Jimal, 1935-38 IMAGE COURTESY OF EBAF

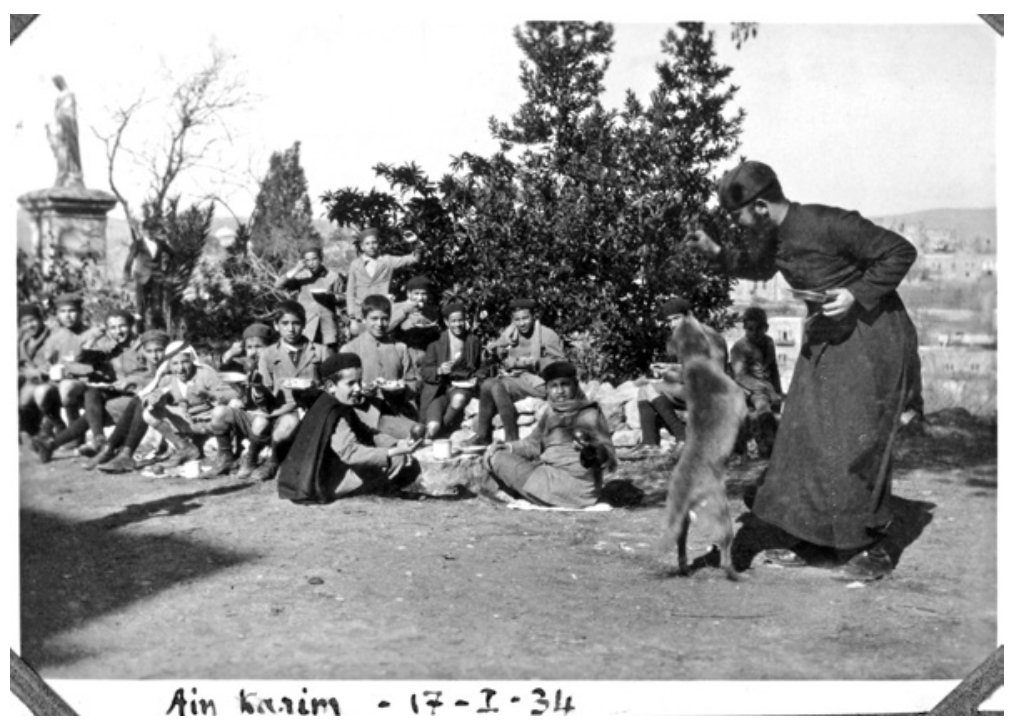

FIGURE 4.27 A class outside, Ain Karim, 17th February 1934. Latin Patriarchate archives, 22572-LPJ, 1669 IMAGE COURTESY OF EBAF 


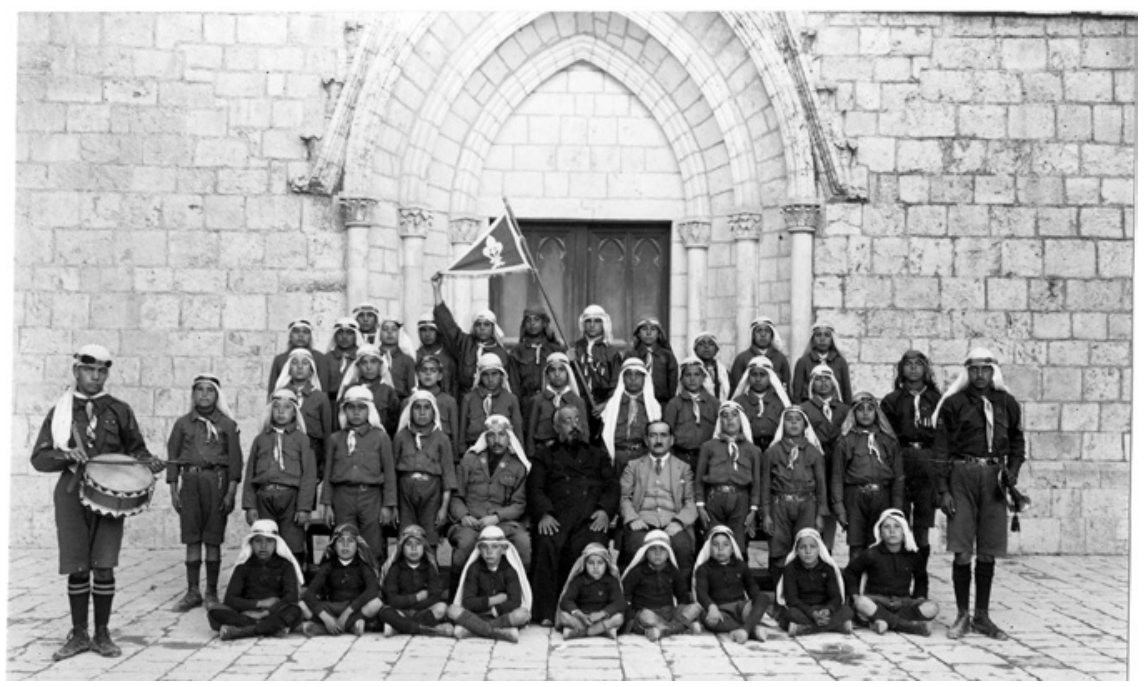

FIGURE 4.28 Catholic scouts of Beit Jala, 1925. Caption behind, 'À Sa Béatitude Mgr. le Patriarche Latin, Jérusalem'. Blue stamp, 'Palestine Catholic Scouts Association. Beit-Jala'. On the sticker: 'I giovani esploratori col loro Parroco D. Bonaventura Habase - 1925'. Latin Patriarchate archives, 2142O-LPJ, O524 IMAGE COURTESY OF EBAF

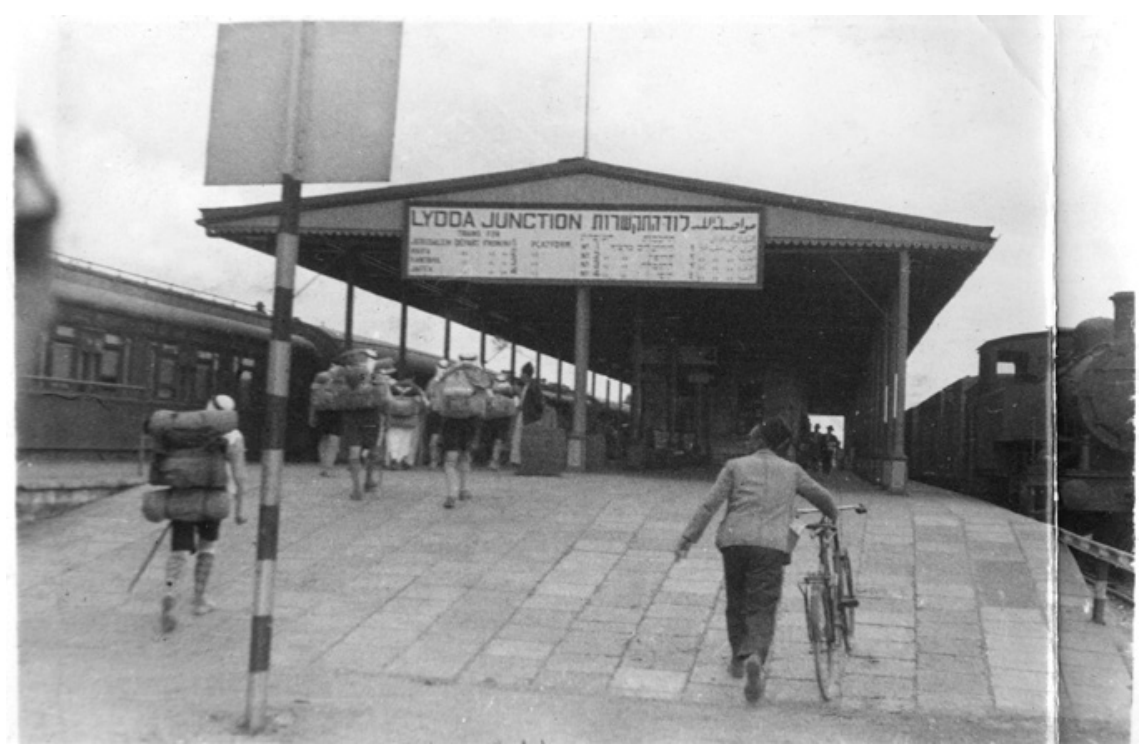

FIGURE 4.29 Catholic scouts in a trip around Palestine, Lydda junction station, 1930 .

Salesians archives, 26489-scouts 28

IMAGE COURTESY OF EBAF 


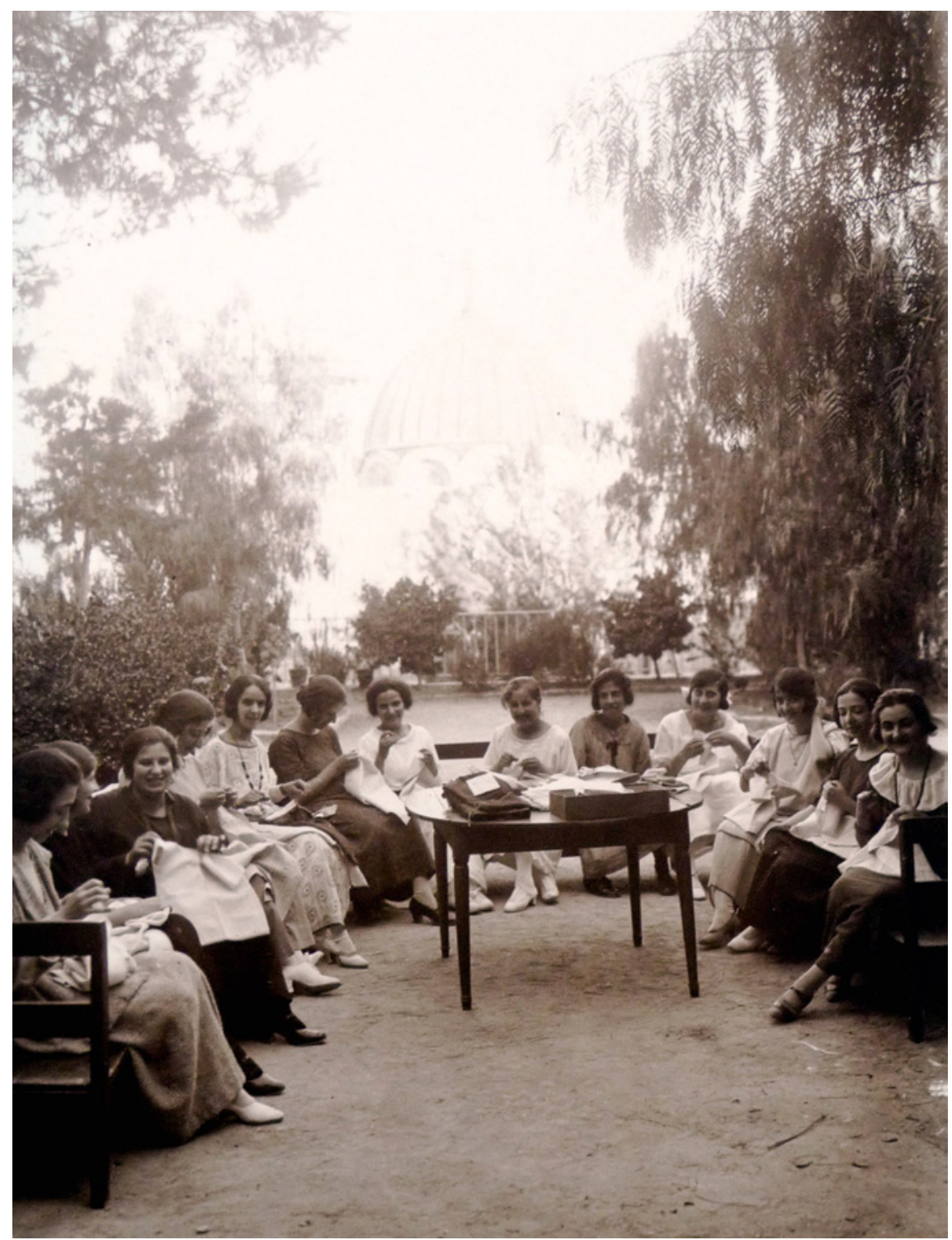

FIGURE 4.30 Alumni of the Sisters of Sion, charity for the poor of the Bab Hutta neighbourhood, 1926. Sisters of Sion Archives

IMAGE COURTESY OF EBAF 


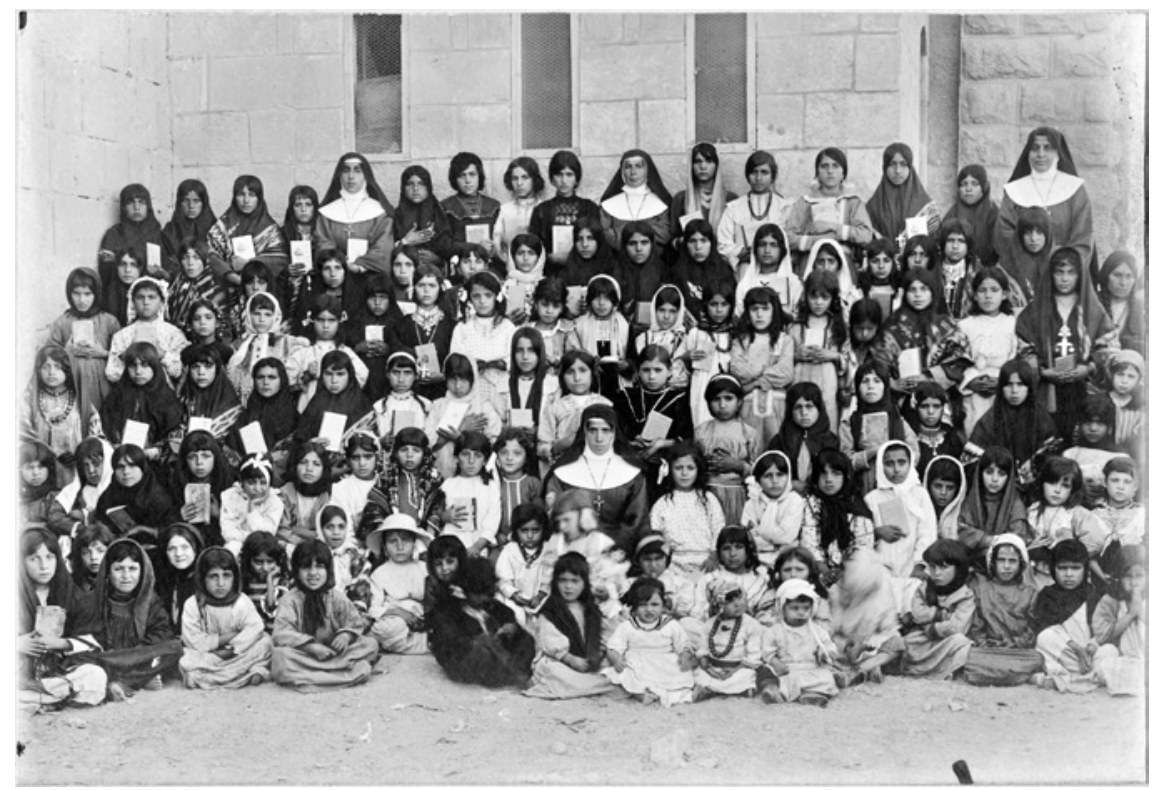

FIGURE 4.31 Rosary sisters and their pupils, Zababdeh, 1933. Archives of the Rosary Sisters, 22188-LPJ, 1293

IMAGE COURTESY OF EBAF

the expressions 'patrimoine', 'patrie' appear in the textual archives) (Fig. 4.29), Salesians scouts in their 'tour of Palestine' in the mid-1940s).

The various schools' photographs also convey views on girls'/women's education and role in Palestinian society. The alumni photographs of the three main Catholic women orders offer glimpses of the activities of women's associations, sometimes linked to political activism or welfare actions (Fig. 4.30, Sisters Sion alumni, charity for the poor families of the neighbourhood of Bab Hutta, Jerusalem). These archives often contain lists of people that can be cross analysed with other archives to understand the activities and potential impact of alumni associations ${ }^{85}$ and trajectories of girls enrolled in these missionary schools. They also reveal the impact of the indigenous Catholic order of the Rosary Sisters (Fig. 4.31 and Fig. 4.32, Rosary Sisters pupils and alumni in Zababdeh in 1933). Created in 1886 by D. Tannous, a local priest, and the only

Arabic as the national language of Palestine (Ordonnance, 1920, LPA) and the knowledge of the geography and history of the region for pupils of Catholic schools.

85 Ellen Fleischmann, The Nation and Its "New" Women: The Palestinian Women's Movement, 1920-1948 (Berkeley: University of California Press, 2003). 


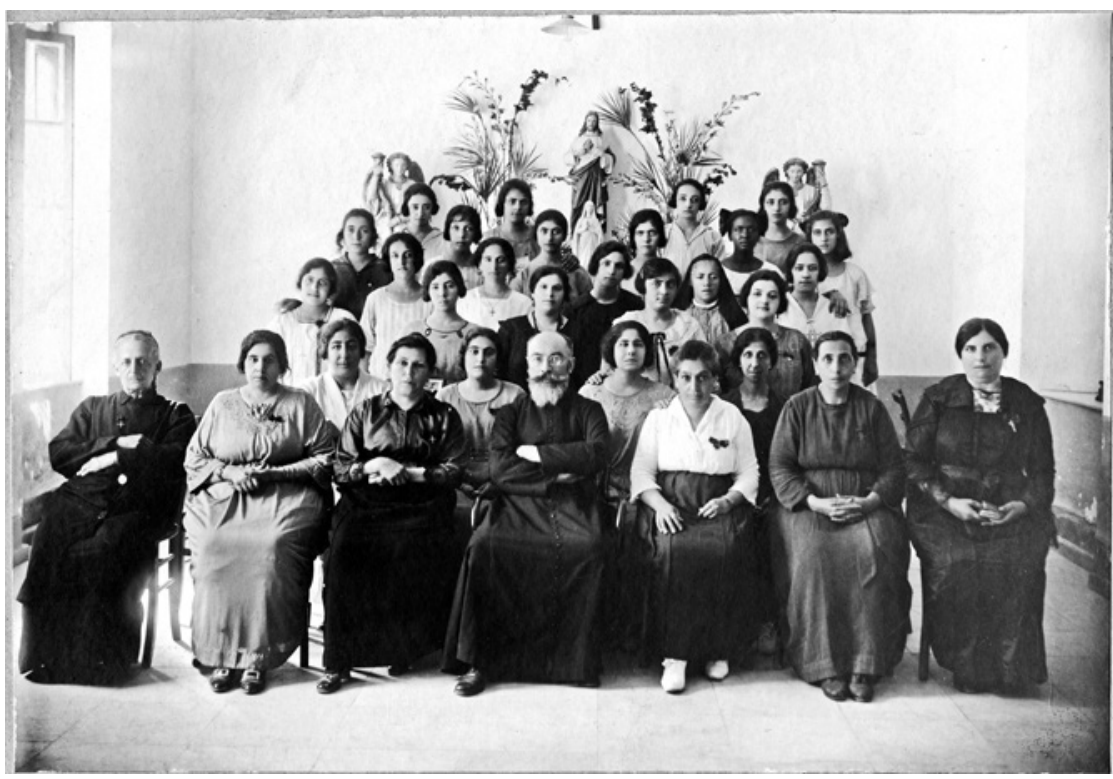

FIGURE 4.32 Rosary Sisters with Alumni and priest, Zababdeh, 1933. Archives of the Rosary sisters, 22189 LPJ 1294

IMAGE COURTESY OF EBAF

Palestinian Catholic congregation, the Rosary sisters expanded in the region and reached remote rural areas. ${ }^{86}$ They promoted girls' education, going further than the Latin Patriarchate schools by teaching all topics in Arabic (here, Fig. 4.33 at Yāffā al-Nāṣariyya, 1922-23). ${ }^{87}$

Other photographs deal with inter-rituality among Catholic communities. The Catholic Procession at Beit Jimal (Fig. 4.34) took place at Corpus Christi. The students from the vocational school frame the canopy under which the priest carries the Blessed Sacrament in procession. The rite is Latin Catholic,

86 Vatican Archives of the Oriental Congregations, Rome, Latini Propaganda Fide, file 451, Suore del Rosario (in Zabaddeh since 1884; in Yāffā al-Nāṣariyya since 1885, school and professional school 'ouvroir') and La congrégation des sœurs du Rosaire de Jérusalem (Paris: J. Gabalda, 1913).

87 In the 1922 census of Palestine conducted by the British Mandate authorities, Yāffā al-Nāṣariyya had a total population of 615; 215 Muslims and 400 Christians; J.B. Barron, ed., Palestine: Report and General Abstracts of the Census of 1922. Government of Palestine; Barron, 1923, Table XI, Sub-district of Nazareth, 38 . The population had increased at the 1931 census, when Yafa had a population of 833; 456 Muslims and 377 Christians, in a total of 213 houses, E. Mills, ed., Census of Palestine 1931. Population of Villages, Towns and Administrative Areas. Jerusalem: Government of Palestine (1932). 


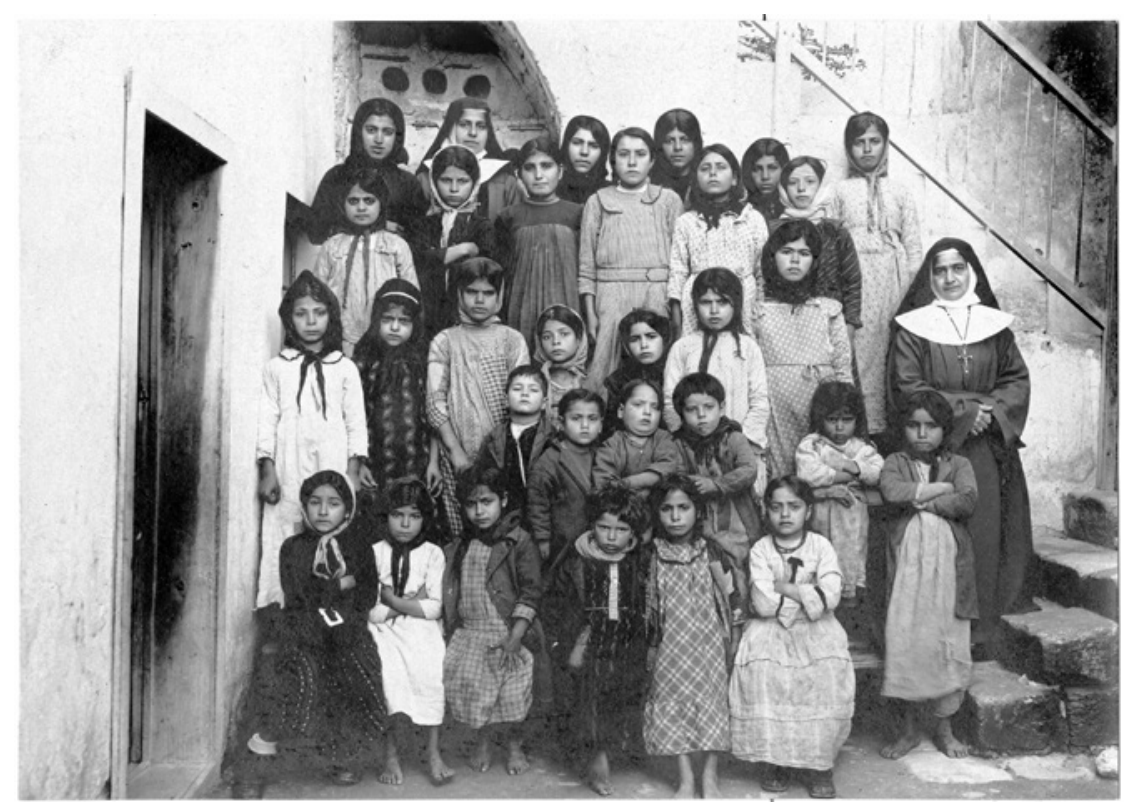

FIGURE 4.33 School for girls in Yaffa en-Nasariyye, 1922-1923. Caption on the back, 'Jaffa de Nazareth. 1922-1923', 'La scuola feminile nel 1920'. Latin Patriarchate archives, 21617-LPJ O721

IMAGE COURTESY OF EBAF

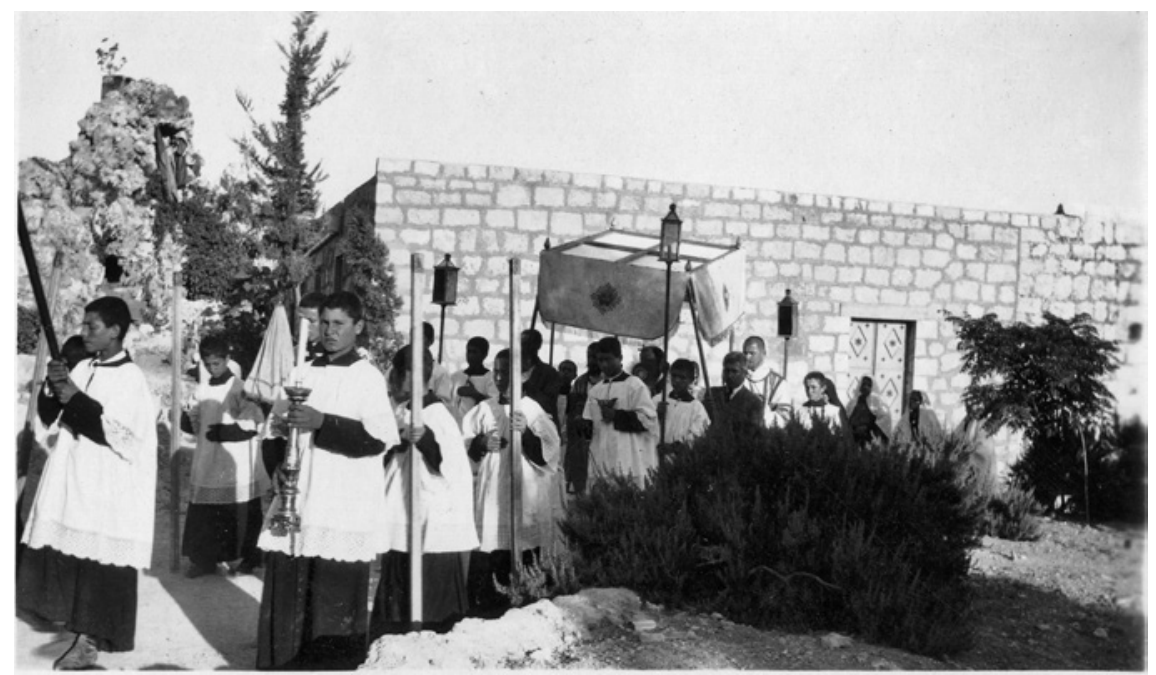

FIGURE 4.34 Latin procession at Beit Jimal, 1935, with Greek-Catholic, Maronite, Armenian Catholic and Syriac Catholics. Salesians archives, 17098 Sal. 100 IMAGE COURTESY OF EBAF 
although the students are Greek-Catholic, Maronite, Armenian Catholic and Syriac Catholic.

Catholic missionaries witnessed the social changes in Palestinian society. They were present in Palestine since the last quarter of the nineteenth century for most of them. For some, they maintained close relations with different parts of Arab Palestinian society, partly reflected on the changes in their diverse visual productions. Producing diverse photographs about rural and urban Palestine and Palestinians, the missionaries also underlined 'the emergence of a cultural divide between mercantile coastal communities and mountain-dwelling smallholder peasants'. ${ }^{88}$ The visual language used during the Ottoman period was still influencing their visual production at the beginning of the 1920s, but they transformed it as society faced rapid changes. At the end of the Mandate period, missionaries documented the social history of Arab Palestinian refugees during and after the Arab-Israeli War and many missionary outposts served as refuge zones: Jerusalem, Jaffa, Bethlehem and Gaza areas (Fig. 4.35 here at the Latin Patriarchate school courtyard in Gaza, food and clothes distribution). ${ }^{89}$

\section{$4 \quad$ Conclusion}

By attempting to analyse the constitution of Catholic missionaries' photographic archives at the EBAF - images not disseminated through the illustrated press, postcards, so not well-known by researchers and wider audiences we hope to contribute to a broader and nuanced redefinition of the British Mandate visual space. To a certain extent, this responds to the call of Ali Behdad for archival awareness in the study of photography. Behdad contends that:

Faced with a seemingly endless, dispersed corpus of visual materials, photographic historians must remain vigilant about the internal differences and histories of archives and about their modes of production and

88 Salim Tamari, Mountain against Sea. Essays on Palestinian Society and Culture (Berkeley: University of California Press, 2008).

89 Maria Chiara Rioli, "Catholic Humanitarian assistance for the Palestinian refugees: The Franciscan Casa Nova of Jerusalem in the 1948 Storm," in Christian Missions and Humanitarianism in the Middle East, 1850-1950. Ideologies, Rhetoric and Practices, eds. Inger Marie Okkenhaug and Karène Sanchez Summerer (Leiden: Brill, 2020), 253-275. 


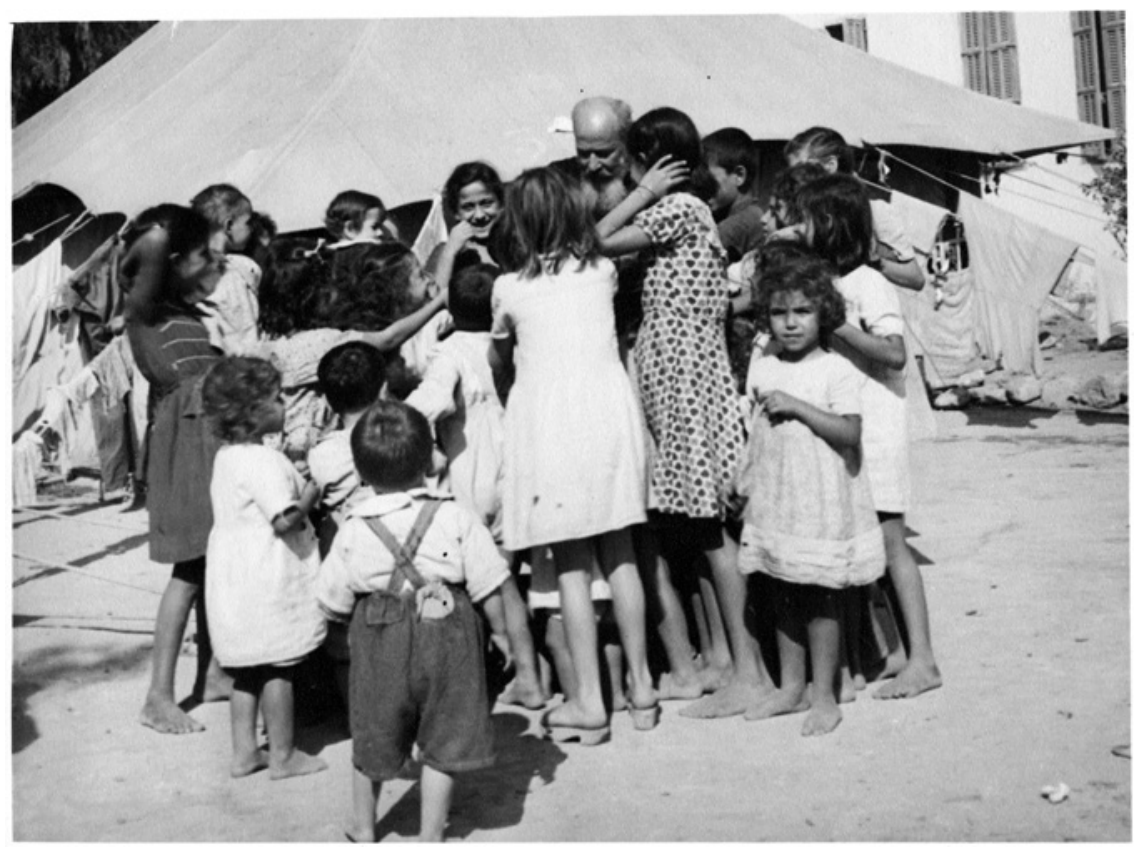

FIGURE 4.35 Food distribution in Gaza, 1948. Caption 'D. Sourour with refugee children'. Latin Patriarchate archives, 21763-LPJ 0868 IMAGE COURTESY OF EBAF

intended purposes, lest the sheer mass of material impose its own logic that occludes the complexities of its subject matter. ${ }^{90}$

This overview resulted from time spent at the EBAF when for the first time our research agendas prompted us to rethink what the EBAF images were telling us about the image maker, the viewer, the way in which images were shared, talked about and the impact of missionary photography on social history. ${ }^{91}$

The way observers such as missionaries have looked at, perceived and understood Arab communities remains largely unknown. Missionary photography cannot therefore be analysed from a single point of view. On the contrary, it must be read from different perspectives. Interest in Palestinian Arab society became progressively more important among Catholic missionaries during the Mandate period. If Palestine is compared to the rest of the 'Holy Land', the

$90 \quad$ Ali Behdad and Luke Gartlan, eds. Photography's Orientalism: New Essays on Colonial Representation (Los Angeles: Getty Publications, 2013), 5 .

Friedrich, The Social Dimension of Christian Missions in the Middle East. 
position of the Catholic missionaries as photographers, is of an idiosyncratic character: it interprets local architectural traditions in a proto-regionalist manner and, to a certain extent, populations, through a plurality of visual narratives. The Mandate period corresponds to an in-between period for Catholic missionaries, adapting their visual approach and production to their adjustment to the mandated control of a non-Catholic European power and to Arab nationalism.

\section{References}

\section{Archives and Sources}

Photographic collection of the EBAF (photothèque)

\section{Diaries of St Stephen priory}

ACJ Archives of the Collège des frères des écoles chrétiennes of Jerusalem

$\mathrm{ACB} \quad$ Archives of the Collège des frères des écoles chrétiennes of Bethlehem

$\mathrm{ACH}$ Archives of the Collège des frères des écoles chrétiennes of Caiffa (Haifa)

AMGPB Archives of the Maison Généralice des Pères Blancs - Rome

ASAJ Archives of Saint Anne of Jerusalem

AssJ Archives of Saint Joseph Sisters

AsZ Archives of Sisters of Zion

Berchem, M. van. "Aux pays de Moab et d'Edom." Extracted from Journal des Savants.

Paris: Imprimerie nationale (July-August- 1909): 33-35.

Canaan, T. Mohammedan Saints and Sanctuaries in Palestine. Jerusalem: Ariel Publishing House, 1927.

Jaussen, A. “Le Cheikh Sa'ad ad-Din et les 'djinn' à Naplouse." Revue Biblique (1905): 145-157.

Jaussen, A. "Trois inscription arabes inédites, du haram d'Hébron." Revue Biblique (January 1923).

Jaussen, A. "Inscriptions coufiques de la chaire du martyr al-Husayn, à Hébron." Revue Biblique (October 1923).

Jaussen, A. "Inscription arabes de la ville d'Hébron." BIFAO (1924).

Jaussen, A. "Inscriptions arabes de Naplouse." BIFAO (1924).

Jaussen, A. Coutumes palestiniennes. I. Naplouse et son district. Paris: Geuthner, 1927.

Jaussen, A. Coutumes des Arabes au pays de Moab. Paris: Adrien-Maisonneuve, 1948. La congrégation des soeurs du Rosaire de Jérusalem. Paris: J. Gabalda, 1913.

Vincent, L.-H., and F.-M. Abel. Hébron. Le Haram el-Khalîl, sépulture des Patriarches. Paris: Leroux, 1923. 


\section{Bibliography}

Abrous, Dahbia and Claudot-Hawad, Hélène. Mimétisme des corps et conquêtes des âmes. Les photographies des Missionnaires d'Afrique (Kabylie, Aurès, Sahara). Paris: Non-lieu, coll. Entre-Rives, 2017.

Aubin-Boltanski, Emma. Pèlerinages et nationalisme en Palestine. Prophètes, héros et ancêtres. Paris: EH Ess, 2007.

Baron, Beth. Egypt as a Woman. Nationalism, gender and politics. Berkeley: University of California Press, 2005.

Barromi, Edna. "Archeology, Zionism and Photography in Palestine: Analysis of the Use of Dimensions of People in Photographs." Journal of Landscape Ecology 10, no. 3 (2017): 49-57.

Beaugé, G., and Pelen, Jean-Noël, eds. "Photographie, ethnographie, histoire. Présentation." Le monde alpin et rhodanien 2-4 (1995): 7-17.

Becker, Judith. Menschen - Bilder - Eine Welt: Ordnungen von Vielfalt in der religiösen Publizistik um 19oo. Veröffentlichungen des Instituts für Europäische Geschichte Mainz - Beihefte, Band 118.

Behdad, Ali and Gartlan, Luke, eds. Photography's Orientalism: New Essays on Colonial Representation. Los Angeles: Getty Publications, 2013.

Bontemps, Véronique. Ville et patrimoine en Palestine. Une ethnographie des savonneries de Naplouse. Paris: Karthala, 2012.

Carney, Gavin. "Bonfils and the Early Photography of the Near East." Harvard Library Bulletin vol 26, no. 4 (1978): 442-470.

Çelik, Zeynep. "Photographing Mundane Modernity." In Camera Ottomana: Photography and Modernity in the Ottoman Empire, 1840-1914, edited by Zeynep Çelik and Edhem Eldem, 154-200. Istanbul: Koç University Press, 2015.

Chatelard, Géraldine and Tarawneh, Mohammed, eds. Antonin Jaussen. Sciences sociales occidentales et patrimoine arabe. Beirut: CERMOC, 1999.

Chatelard, Géraldine and de Tarragon, Jean-Michel. L'Empire et le royaume. La Jordanie vue par l'École biblique et archéologique française de Jérusalem (1893-1935). Amman: Centre culturel français d'Amman, 2006.

Clark, Terry. Prophets and Patrons: the French University and the Emergence of the Social Sciences. Cambridge: Harvard University Press, 1973.

Dakhlia, Jocelyne. "Entrées dérobées: l'historiographie du harem." Clio. Histoire, femmes et sociétés 9 (1999): 1-13. Available via http://journals.openedition.org/clio/282.

Depaule, Jean-Charles. "Archiver des photographies au Proche Orient: La Fondation arabe pour l'image." In Archiver au Moyen-Orient, Fabriques documentaires contemporaines, edited by Christine Jüngen and Jihane Sfeir, 157-19o. Paris: Karthala, 2019.

Doumani, Bishara. Rediscovering Palestine: Merchants and Peasants in Jabal Nablus, 1700-1900. Berkeley: University of California Press, 1995. 
Escande, Renault. "Un jeu de regards: la photographie de Jaussen et Savignac à travers la croisière de l'Ecole pratique d'Etudes bibliques autour de la mer Morte." In Antonin Jaussen. Sciences sociales occidentales et patrimoine arabe, edited by G. Chatelard and M. Tarawneh, 107-120. Beirut: CERMOC, 1999.

Eyal, Onne. The Photographic Heritage of the Holy Land, 1839-1914. Manchester: Manchester Polytechnic, 1980.

Fleischmann, Ellen. The Nation and Its "New" Women: The Palestinian Women's Movement, 1920-1948. Berkeley: University of California Press, 2003.

Fournié, Pierre. and Riccioli, Jean-Louis. La France et le Proche-Orient, 1916-1946, Une chronique photographique de la présence française en Syrie et au Liban, en Palestine au Hedjaz et en Cilicie. Paris: Casterman, 1996.

Friedrich, Norbert, Kaminsky, Uwe, and Löffler, Roland, eds. The Social Dimension of Christian Missions in the Middle East. Historical studies of the 1gth and 2oth Centuries. Stuttgart: Franz Steiner Verlag, 2010.

Garrigues, Emmanuel. “Le savoir ethnographique de la photographie." L'Ethnographie 109, 87-1 (1991): 11-54.

Geary, Christraud. "Missionary photography: private and public readings." African Arts 24, no. 4 (1992): 48-59.

Geary, Christraud, and Jenkins, Paul. "Photographs from Africa in the Basel Mission archive." African Arts 18, no. 4 (1985): 56-63.

Graham-Brown, Sarah. Palestinians and their Society 1880-1946. A photographic Essay. London: Quarter Books, 198o.

Graham-Brown, Sarah. “The Political Economy of Jabal Nablus, 1920-1948." In Studies and Social History of Palestine in the Nineteenth and Twentieth Centuries, edited by Roger Owen, 88-176. London/Basingstoke: Macmillan, 1982.

Halabi, Awad, "Islamic Ritual and Palestinian Nationalism: al-Hajj Amin and the Prophet Moses Festival in Jerusalem, 1921 to 1936." In Jerusalem Interrupted: Modernity and Colonial Transformation 1917-Present, edited by Lena Jayyusi, 139-161. Northampton, MA: Interlink Publishing, 2013.

Hugon, Anne. "Aspect de la propagande missionnaire." In Images et colonies. Nature, discours et influence de l'iconographie coloniale liée à la propagande coloniale et à la représentation des Africains et de l'Afrique en France, de 1920 aux Indépendances, edited by P. Blanchard and A. Chatelier, 77-84. Paris: ACHAC et Syros, 1993.

Jalabert, Cyrille. “De l'exégèse biblique au monde arabe." In Antonin Jaussen. Sciences sociales occidentales et patrimoine arabe, edited by G. Chatelard and M. Tarawneh, 65-72. Beirut: CERMOC, 1999.

Jenkins, Paul. "The earliest generation of missionary photographers in West Africa: The portrayal of Indigenous people and culture." Visual anthropology 7 (1994): 99-118.

Jenkins, Paul. "On using historical missionary photographs in modern discussion." Le Fait Missionnaire no. 10 (January 2001): 71-87. 
Jenkins, Paul. "Sources of unexpected light. Experiences with old mission photographs in research on overseas history." Jarhbuch für Europaische Uberseegeschichte 1 (2001): 157-167.

Khalidi, Rashid. The Iron cage. The Story of the Palestinian Struggle for Statehood. Boston: Beacon Press, 2007.

Khalidi, Walid. Before Their Diaspora, A Photographic History of the Palestinians 18761948. Washington D.C.: Institute for Palestine Studies, 1991.

Khemir, Mounira. L'orientalisme. L'Orient des photographes au xixe siècle. Paris: Photo-Poche, 1994.

Laurens, Henry. “Jaussen en Arabie." In Photographies d'Arabie, Hedjaz 1907-1917, edited by Brahim Alaoui, PAGE NUMBERs. Paris: IMA, 1999.

Laurens, Henry. "Jaussen et les services de renseignement français (1915-1919)." In Antonin Jaussen. Sciences sociales occidentales et patrimoine arabe, edited by Géraldine Chatelard and Mohamed Tarawneh, 23-35. Beirut: CER MOC, 1999.

Makariou, Sophie. "Van Berchem Max." In Dictionnaire des orientalistes de langue française, edited by François Pouillon, 948-949. Paris: IIS MM/Karthala, 2008.

Malti-Douglas, F. Woman's Body, Woman's Word: Gender and Discourse in Arabo-Islamic Writing. Princeton: Princeton University Press, 1991.

Mazza, Roberto. "Transforming the Holy City: From Communal Clashes to Urban Violence, the Nebi Musa Riots 1920." In Urban Violence in the Middle East Changing Cityscapes: The Transition from Empire to Nation State, edited by Ulrike Freitag, Nelida Fuccaro, Claudia Ghrawi and Nora Lafi, 179-94. New York: Berghahn, 2015.

Mazza, Roberto and Ouahes, Idir. "For God and la Patrie: Antonin Jaussen Dominican and French Agent in the Middle East 1914-1920." First World War Studies 3, no. 2 (2012): 145-164.

Merli, Andrea. "A New Art in an Ancient Land: Palestine through the lens of early European Photographers." Jerusalem Quarterly 50 (2012): 23-36.

Métral, Jean. "Naplouse et son district: un essai de monographie urbaine." In Antonin Jaussen. Sciences sociales occidentales et patrimoine arabe, edited by Géraldine Chatelard and Mohammed Tarawneh, 121-135. Beirut: CERMOC, 1999.

Montagnes, Bernard. Marie-Joseph Lagrange, Une biographie critique. Paris: Le Cerf, 2005 .

Moors, Annelies. “From 'Women's Lib.' to 'Palestinian Women': The Politics of Picture Postcard in Palestine/Israel." In Visual Culture and Tourism, edited by David Crouch and Nina Lubbren, 23-39. Oxford and New York: Berg Publishers, 2003.

Nassar, Issam. "Familial Snapshots. Representing Palestine in the Work of the First Local Photographers." History \& Memory 18, no. 2 (2006): 139-155.

Nassar, Issam. "Biblification' in the Service of Colonialism. Jerusalem in Nineteenthcentury Photography." Third Text 20, no. 3 (2007): 317-26. 
Palestine Exploration Fund. "Christ Church archives Shimon Gibson." Jerusalem in Original Photographs, 1850-1920. London: Stacey International, 2003.

Pérennès, Jean-Jacques. Le Père Antonin Jaussen, o.p., (1871-1962). Une passion pour l'Orient musulman. Paris: Cerf, 2012.

Perez, Nissan. Visions d'Orient. Jerusalem: Israel Museum, 1995.

Pirotte, Jean. "La mobilisation missionnaire, prototype des propagandes modernes." In La mission en textes et en images, edited by C. Paisant. Paris: Karthala, 2004.

Raison-Jourde, Françoise. "Image missionnaire française et propagande coloniale." In Images et colonies. Iconographie et propagande coloniale sur l'Afrique française de 1880 à 1962, edited by Nicolas Bancel, Pascal Blanchard, and Laurent Gervereau, 50-57. Nanterre: BDIC, 1993.

Réseau Barnabé. Regards sur l'éducation chez les Chrétiens d'Orient, À travers le fonds photographique ancien (1890-1930) de l'Ecole biblique et archéologique française de Jérusalem. Publication à l'occasion de l'exposition, Héritage architectural, Réseau Barnabé, 2014.

Revel, Jacques, ed. Une école pour les sciences sociales. De la VIe section de l'EPHE, à l'École pratique des hautes études en sciences sociales. Paris: Le Cerf, 1996.

Rioli, Maria Chiara. "Catholic Humanitarian assistance for the Palestinian refugees: The Franciscan Casa Nova of Jerusalem in the 1948 Storm." In Christian Missions and Humanitarianism in the Middle East, 1850-1950. Ideologies, Rhetoric and Practices, edited by Inger Marie Okkenhaug and Karène Sanchez Summerer, 253-275. Leiden: Brill, 2020.

Roberts, Mary, and Hackforth-Jones, Jocelyn. "Introduction: Visualizing Culture across the Edges of Empires." In Edges of Empire: Orientalism and Visual Culture, edited by Jocelyn Hackforth-Jones and Mary Roberts, 1-19. Oxford: Blackwell Publishing, 2005.

Sanbar, Elias, ed.Jérusalem et la Palestine. Photographies de l'Ecole Biblique de Jérusalem. Paris: Hazan, 2013.

Sanbar, Elias. Les Palestiniens. La photographie d'une terre et de son peuple de 1839 à nos jours. Paris: Hazan, 2004.

Sanchez Summerer, Karène. "Ouvrir les trésors de la charité aux enfants dévoyés d'Abraham - L'action éducative des sœurs de Sion en Palestine ottomane et mandataire (186o-1948)." In Judaïsme, école et mission en Méditerranée à l'heure coloniale, edited by Jérôme Bocquet, 207-238. Rennes: Presses universitaires de Rennes, 2010.

Sanchez Summerer, Karène. "Réception et impacts de l'action éducative et sanitaire des sœurs de Saint Joseph (Naplouse) et des sœurs de Sion (Jérusalem) par les populations musulmanes rurales et urbaines (1870-1940)." In Histoire et Missions chrétiennes no. 22, edited by Nadine Beligand and Philippe Bourmaud, 163-196. Paris: Karthala, 2012. 
Sanchez Summerer, Karène. "Entre négligence et secret. Entreprises archivistiques en Palestine." In Archiver au Moyen-Orient, Fabriques documentaires contemporaines, edited by Christine Jüngen and Jihane Sfeir, 79-102. Paris: Karthala, 2019.

Sanchez Summerer, Karène and Turiano, Annalaura. "Les archives de l'Associazione nazionale per soccorrere i Missionari italiani all'Estero (ANSMI): (Re) découverte d'un fonds, projet de préservation et perspectives de recherche." MEFRIM, 132, no 2 (2020).

Sharkey, Heather. Unexpected Consequences of Christian Missions in the Middle East, Africa and South Asia. Syracuse: Syracuse University Press, 2013.

Stanczak, Gregory. Visual research methods Image Society and Representations. Thousand Oaks, CA: SAGE Publications, 2007.

Tamari, Salim. Mountain against Sea. Essays on Palestinian Society and Culture. Berkeley: University of California Press, 2008.

Taraud, Christelle. Mauresques: femmes orientales dans la photographie coloniale 18601910. Paris: Albin Michel, 2003.

Tarragon, Jean-Michel de. "Ethnographie." In L'Ancien testament. Cent ans d'exégèse à l'École biblique. Cahier de la Revue Biblique 28, 19-44. Paris: Gabalda, 199 o.

Tarragon, Jean-Michel de. "The photographic library of the Dominicans of Jerusalem." In Jérusalem et la Palestine, Photographies de l'Ecole Biblique de Jérusalem, edited by Elias Sanbar, 163-175. Paris: Hazan, 2013.

Tarragon, Jean-Michel de. "Holy Land Pilgrimage through Historical Photography." Jerusalem Quarterly 78 (2019): 93-111. Available via https://www.palestine-studies. org/sites/default/files/jq-articles/Pages_from_JQ_78_-_Tarragon_1.pdf.

The First Century of Photography: Photography as History/ Historicizing Photography in Ottoman territories (1839-1939). Workshop organized by Boğaziçi University Archives and Document Center, RCAC (Research Center for Anatolian Civilization), and IFEA (Institut Francais d'Études Anatoliennes), İstanbul and Aix Marseille University, LabExMed \& IDEMEC, 19-21 June 2018, https:/anamed.ku.edu.tr/ wp-content/uploads/2018/o8/The_First_Century_of_Photography_ANAMED-1.pdf.

Thompson, T. Jack. "Xhosa missionaries to Malawi: Black Europeans or African Christians?" International Bulletin of Missionary Research 24, no. 4 (2000): 168-170.

Thompson, T. Jack. Light on Darkness?: Missionary Photography of Africa in the Nineteenth and Early Twentieth Centuries, Studies in the History of Christian Missions. Grand Rapids, MI: Wm. B. Eerdmans Publishing, 2012.

Trimbur, Dominique. "A French Presence in Palestine - Notre-Dame de France." Bulletin du Centre de recherche français à Jérusalem no. 3 (1998): 117-140.

Trimbur, Dominique. "Sainte Anne, lieu de mémoire et lieu de vie français à Jérusalem." Chrétiens et sociétés XVI ${ }^{e}-X X^{e}$ siècles Bulletin 7 (2000): 39-69. 
Trimbur, Dominique. Une école française à Jérusalem. De l'École Pratique d'Etudes bibliques des Dominicains à l'Ecole Biblique et Archéologique Française de Jérusalem. Paris: Le Cerf, 2002.

Varisco, Daniel. "Orientalism and Bibliolatry. Framing the Holy Land in Nineteenth Century Protestant Bible Customs Texts." In Orientalism Revisited: Art, Land and Voyage, edited by Ian Richard Netton, 187-204. London: Routledge, 2013.

Villeneuve, Estelle, Nieuvarts, Jacques, Marchadour, Alain, and Grière, Benoît. Terre sainte. Les premières photographies. Paris: Bayard, 2010.

Woodward, Michelle. "Between Orientalist Clichés and Images of Modernization." History of Photography 27, no. 4 (2003): 363-374.

Zananiri, Sary. "From Still to Moving Image: Shifting Representation of Jerusalem and Palestinians in the Western Biblical Imaginary", Jerusalem Quarterly 67 (2016): $64-81$. 